\title{
Structural and Stratigraphical Interpretation of Seismic Profiles along Safed Koh Trend (Eastern Part of Sulaiman Fold Belt), Pakistan
}

\author{
Shazia Asim ${ }^{1, *}$, Shahid Nadeem Qureshi ${ }^{2}$, Qasim Mirza ${ }^{3}$, Umer Saleem $^{4}$, Sajjad Ali ${ }^{1}$, Mohammad Haroon $^{1}$, \\ Mohammad Tahir ${ }^{1}$ \\ ${ }^{1}$ Quaid-i-Azam University, Pakistan
${ }^{2}$ Comsats institute of Information Technology (CIIT) Pakistan \\ ${ }^{3}$ Nespak, Pakistan \\ ${ }^{4}$ Norwegian University of Science and Technology (NTNU) \\ *Corresponding Author: shazia@qau.edu.pk
}

Copyright (c) 2014 Horizon Research Publishing All rights reserved.

\begin{abstract}
Safed-koh Trend is located in D.G.Khan district, Punjab province, Pakistan. It is a north south trending fold belt that lies in Eastern Part of Sulaiman Fold Belt. Seismic data correlation is done with the help of well data, Formations' tops, Synthetics and general stratigraphy of the area. The Structural and Stratigraphical interpretation shows subsurface variations. Depth model shows Dhodak, Rodho, Afiband and Zindapir anticlines, the four culminations of Safed-Koh Trend without marking the faults. Dhodak is a northern lower most culmination. Zindapir is the most uplifted one and broader structure comparatively that lies at southern edge. 3D subsurface Time \& Depth models of Rubbly Limestone, Dunghan Formation, Pab Sandstone, Lower Goru Formation and Chiltan Limestone map Dhodak anticlinal structure with reverse faults at its flanks. Dunghan, Ranikot, Pab and Chiltan Formations in this area have already proved to be good quality reservoirs for gas. Pab Sandstone and sands of Lower Goru Formation of Cretaceous and Chilton Limestone of Jurassic age could also be the important reservoirs in unexplored area. Rock Physics analysis of Chilton Formation confirms the hydrocarbon potential.
\end{abstract}

Keywords Structural and Stratigraphical Interpretation, Safed Koh Trend

\section{Introduction}

Research area comprises of Safed Koh Trend, a first line of folding of Sulaiman Fold Belt, Pakistan (fig.1). It is located between: $70^{\circ} 15^{\prime} \mathrm{E}-70^{\circ} 30^{\prime} \mathrm{E} \& 30^{\circ} 15^{\prime} \mathrm{N}-31^{\circ} \mathrm{N}$.

\section{Previous Work Done}

A generalized view is obtained by the efforts of various authors :

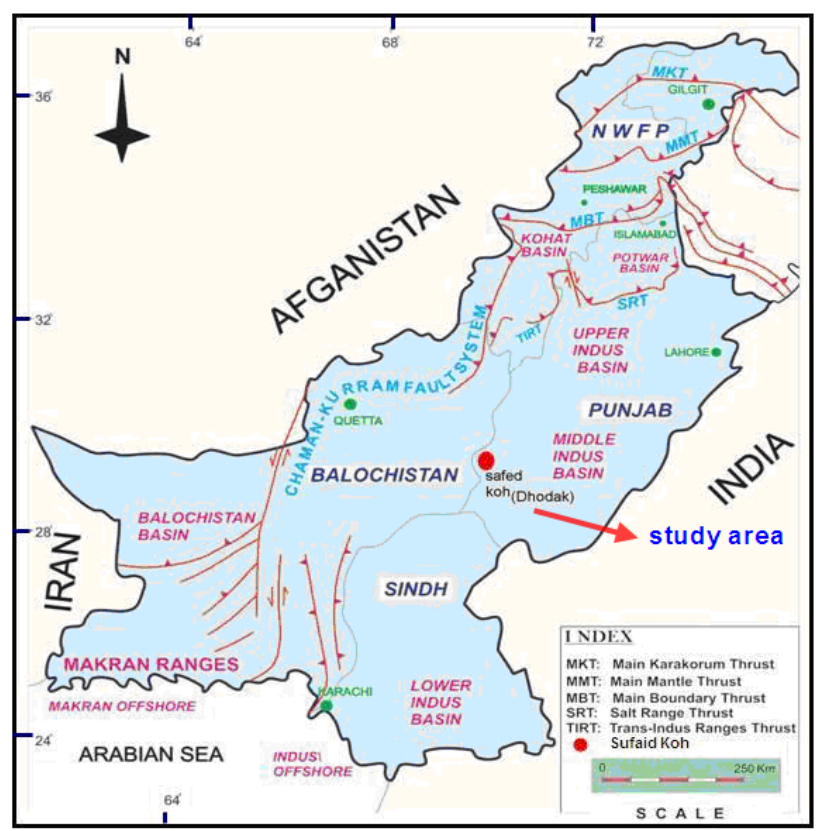

Figure 1. Map showing the location of the Research Area. (www.msnmap.com)

Humayon et al. (1991) and Jadoon et al. (1994) interpretated structurally the eastern \& central Sulaiman Foldbelt, on the basis of surface geology and seismic analysis. According to them the sedimentary strata was detached from the basement with a floor thrust in Paleozoic strata and roof-thrust in Cretaceous (Sembar Formation) except in the frontal part of the Sulaiman Foldbelt where it occurs in Eocene sequences. Kemal et al; (1991) consider East Sulaiman structural play of narrow straight anticlines as 
Flower Structure due to large scale distributive wrench faulting. Muhammad Iqbal et al., (2004) suggest basement of the Indo-Pakistan is involved in structural deformation of Zindapir Anticlinorium and its surroundings. Lillie et al. (1987), Humayun et al. (1991) and Jadoon et al. (1992) believed there is a basal decollement in pelitic rocks or fine carbonates above the crystalline basement at a depth more than $11 \mathrm{~km}$.

\section{Objectives}

Main objectives of the research in this area are stratigraphic correlation with the help of well data and seismic sections, to study the subsurface Structures, generation of 3D models of Dhodak anticline and preparation of depth cross section of Safed Koh Trend.

This study is beneficial in the various relevant fields such as Petroleum geology, Sedimentology, Seismic Stratigraphy, Structural geology, Tectonics and Geodynamics for researchers and industries.

\section{Available Data}

The available data is in the form of Seismic Reflection (filtered and migrated) Sections and well data along with the Formation tops. Locations of Seismic lines along with the settlements are marked on Basemap (fig $2 \& 3$ ).

805-SK-26 SP 101 - SP 34324 km (approx.)

855-SK-33 SP 38 - SP 67164 km (approx.)

785-SK-04 SP155-SP591 33 km(approx.)

Some additional lines are used:

795-SK-06， 795-SK-06A， 795-SK-07， 805-SK-17, 805-SK-18, 805-SK-19, 805-SK-20， 805-SK-22， 805-SK-23 and 805-SK-26.

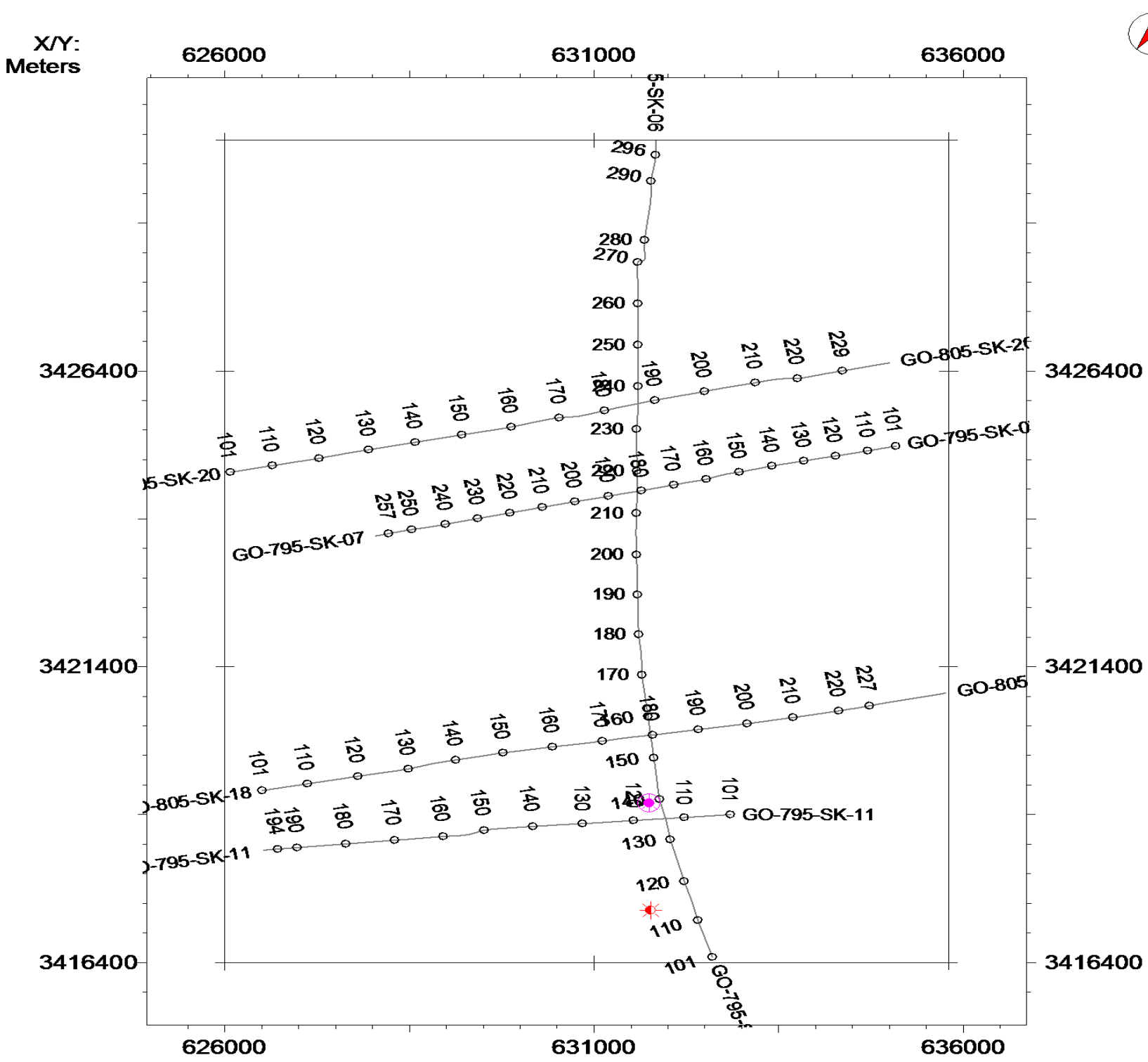

Figure 2. Basemap of the area showing seismic lines used in Dhodak structure study. 


\section{Well Information}

The well data is used for the following wells :

Rhodho - 01, Dhodak - 01, Afiband - 01 and Zindapir - 01

\section{Central Indus Basin}

Research area lies in the Central Indus Basin of Pakistan (fig 1).

Central Indus may be divided into following broad tectonic divisions (from east to west):

(1) Punjab Platform (2) Sulaiman Depression (3) Sulaiman Fold belt. (Kadri, 1995).

The basin is separated from Upper Indus Basin by the Sargodha High \& Pezu uplift in north. It is bounded by Indian shield in the east, marginal zone of Indian Plate in the west, and Sukkur rift in the south. It is the Sargodha high which is considered to be a divide between Upper Indus Basin \& Lower Indus Basin (Kadri, 1995). Khairpur-Jacobabad High divides the Lower Indus basin further into two basins namely Southern and Central Indus Basin. The Southern \& Central Indus Basins are separated by Jacobabad \& Mari Kandhkot highs together termed as the
Sukkur Rift (Raza et al, 1989). Safed Koh is bounded in east by Sulaiman Foredeep, in west by Sualiman Fold and Thrust Belt, in north by Pezu |Uplift and south by Mari Bugti (fig 3). General stratigraphy of area is given in fig 4. Safed Koh Block along with the four culminations is shown in fig 5 .

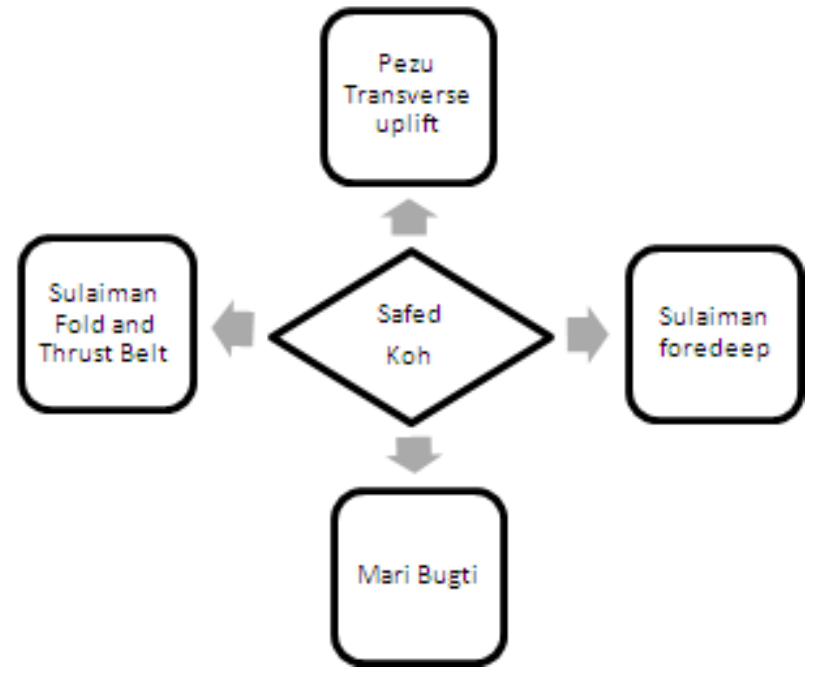

Figure 3. Geological and tectonic boundaries of Safed Koh.

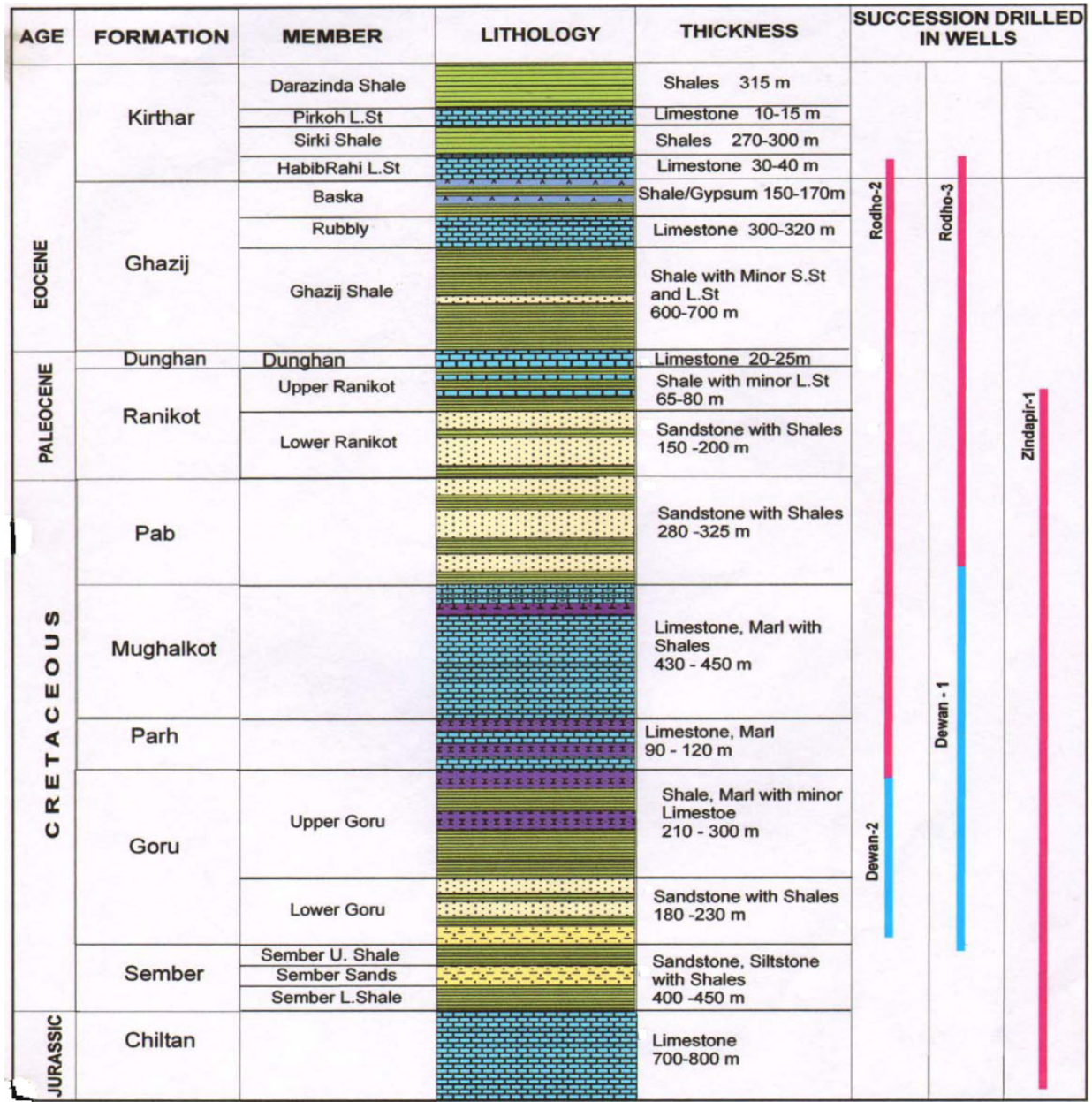

Figure 4. Stratigraphy of Safed Koh Trend (www.msn.com) 


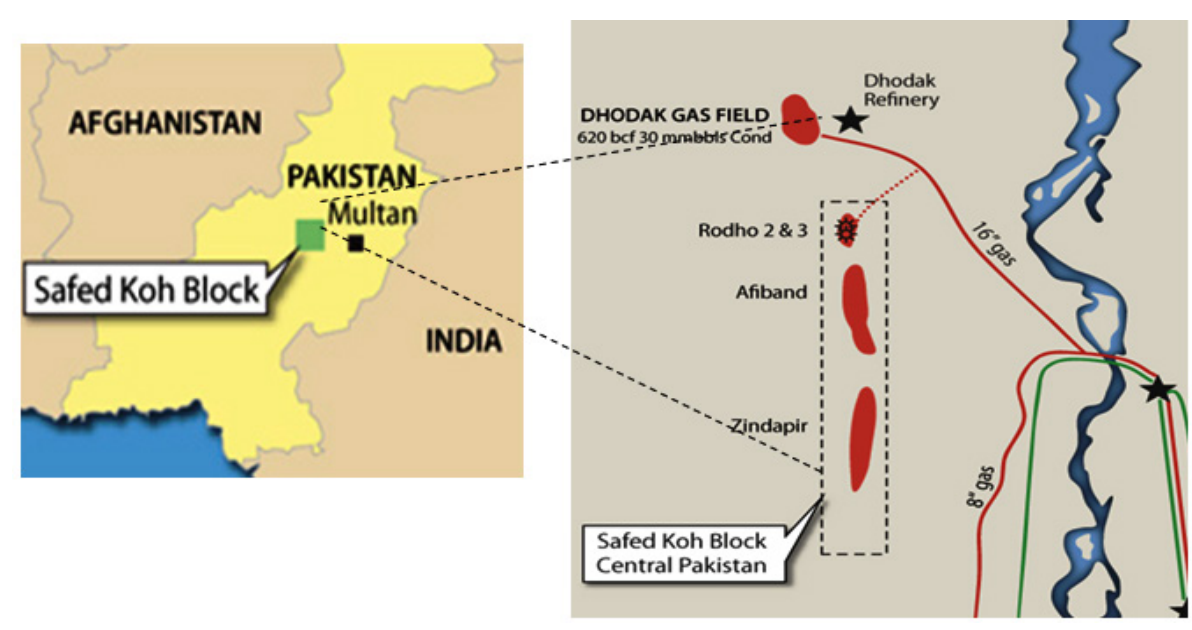

Figure 5. Gas Fields in Safed Koh Block (Courtesy: Dewan Petroleum website)

\section{Seismic Interpretation}

Seismic sections for Dhodak anticline are interpreted showing a popup structure bounded by reverse faults. Formation sequence from Uppermost is Rubbly Limestone, Dunghan Formation, Lower Goru Formation and Chiltan Formation is lower most respectively. The study area is dominated by Reverse/Thrust Faulting as the area is deformed by the compression tectonics. The interpreted seismic sections and depth sections using the lateral variations of average velocities are prepared (fig 6-10). The Time and depth contours and the 3D structural view of these formations gives a subsurface view of Dhodak Anticline (fig 11-20)

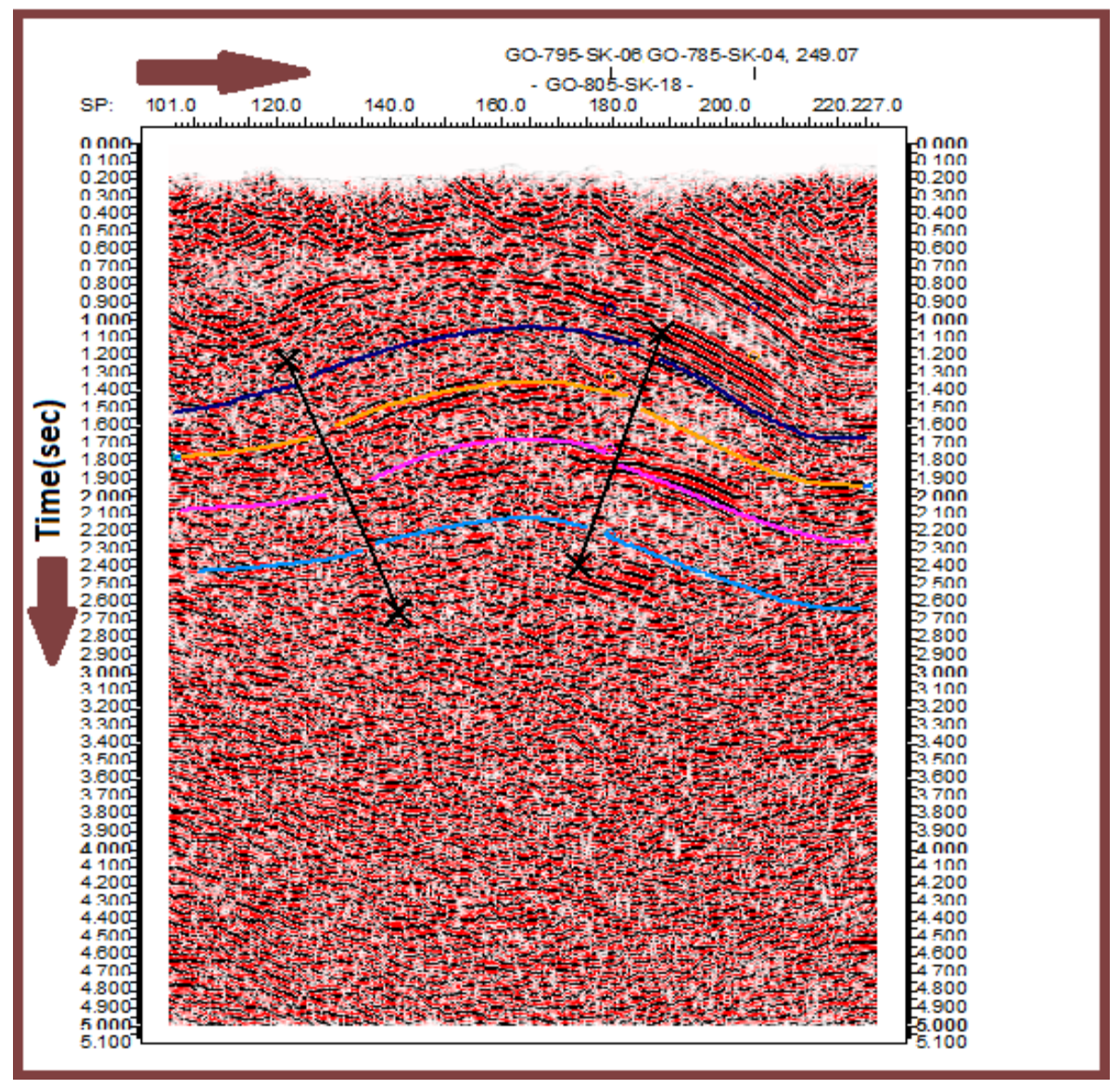

Figure 6. Interpreted Seismic section of 805-SK-18 (formation sequence from Uppermost is Rubbly Limestone, Dunghan Formation, Lower Goru Formation, Chiltan Formation) 


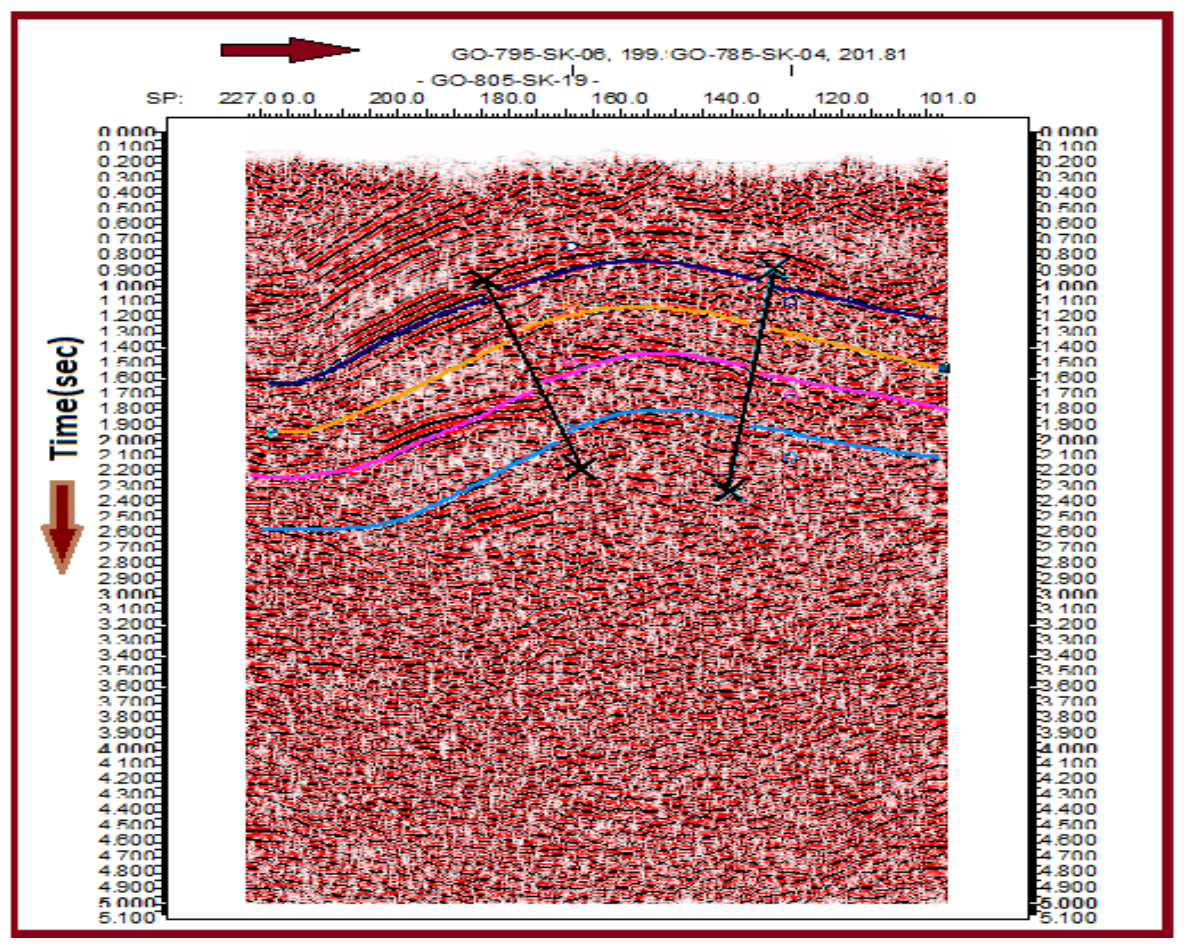

Figure 7. Interpreted Seismic section of 805-SK-19 (formation sequence from Uppermost is Rubbly Limestone, Dunghan Formation, Lower Goru Formation, Chiltan Formation)

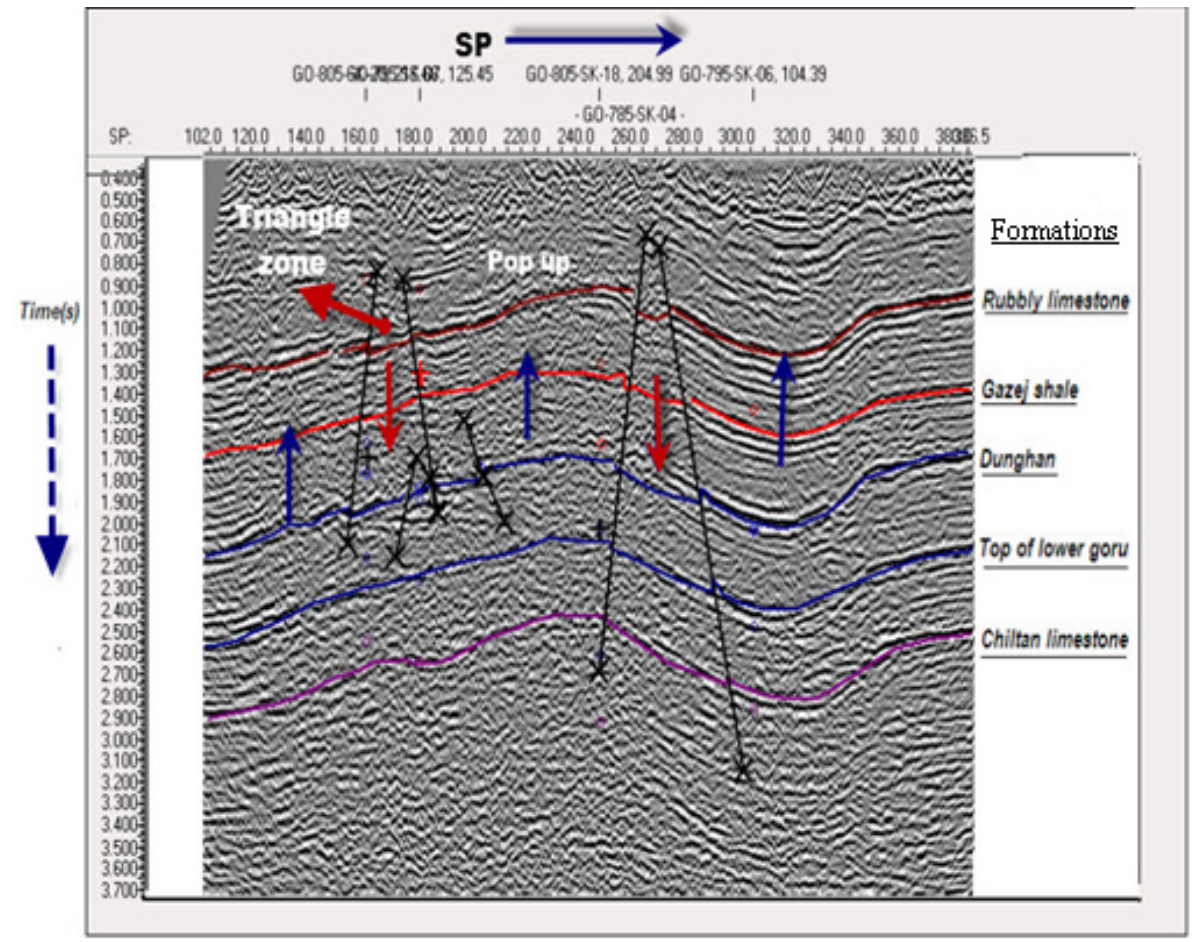

Figure 8. Interpreted Seismic section of 785-SK-04 


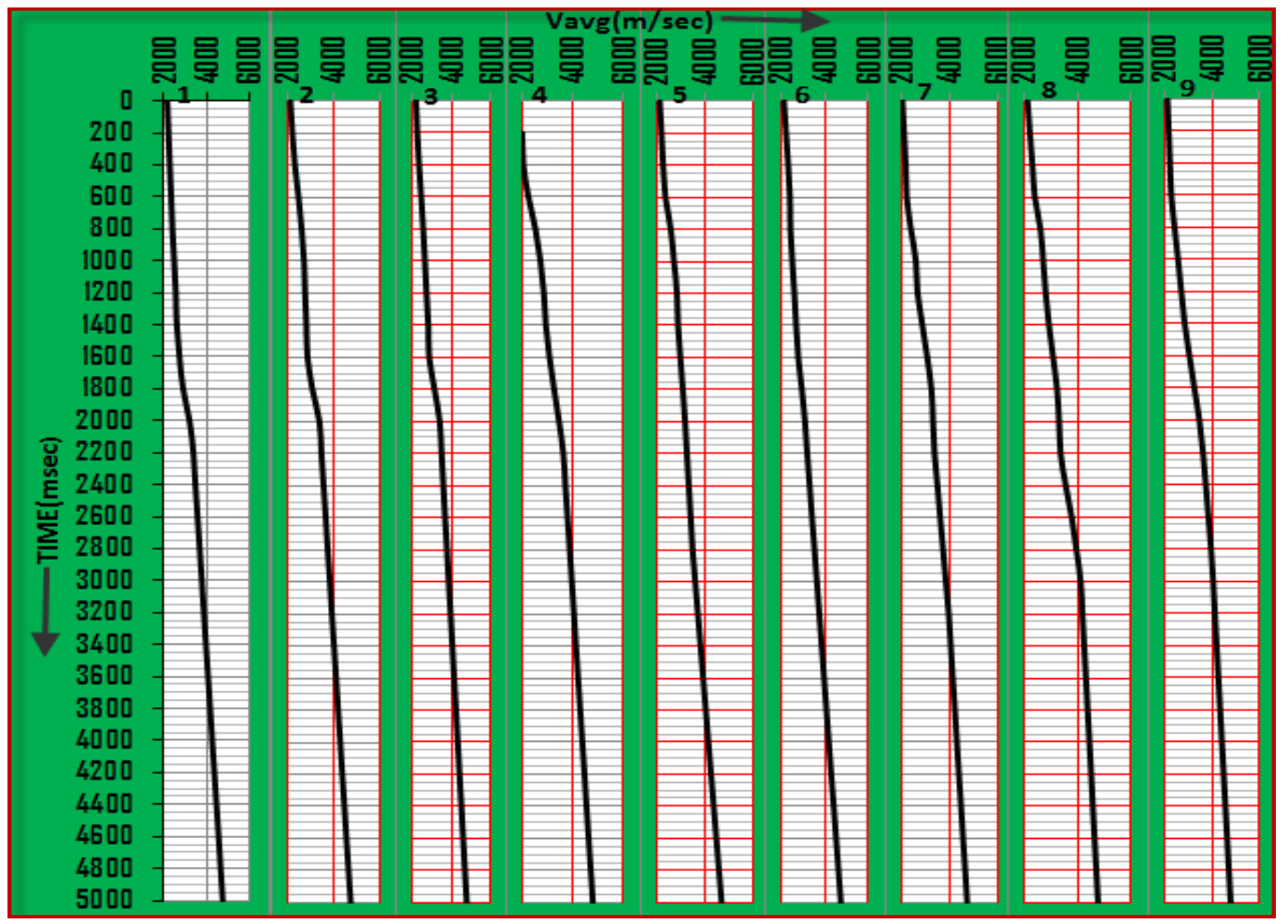

Figure 9. Average Velocity used for depth computation

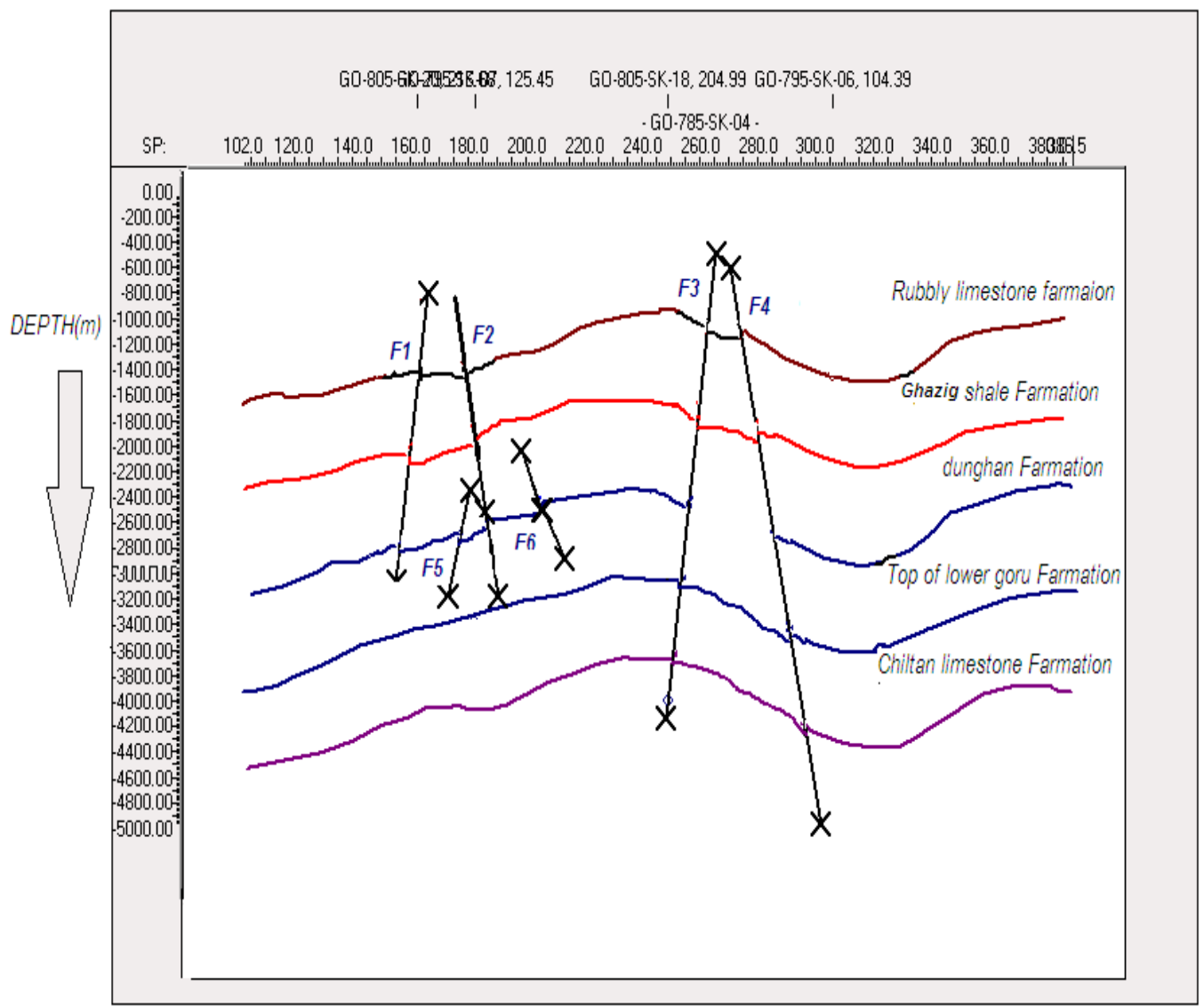

Figure 10. Depth section of $785-\mathrm{SK}-04$ 


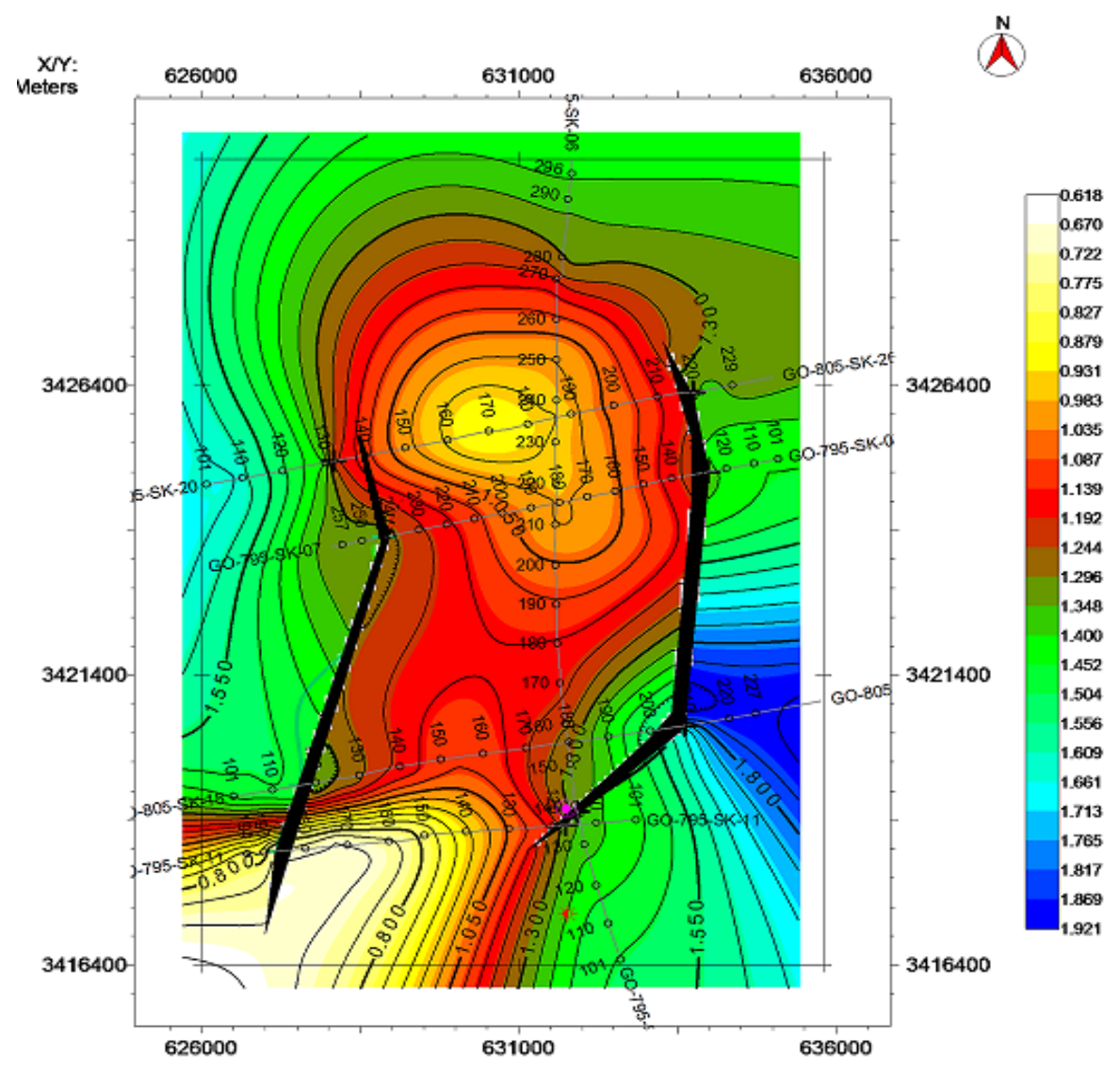

Figure 11. Time contour map of Rubbly Limestone

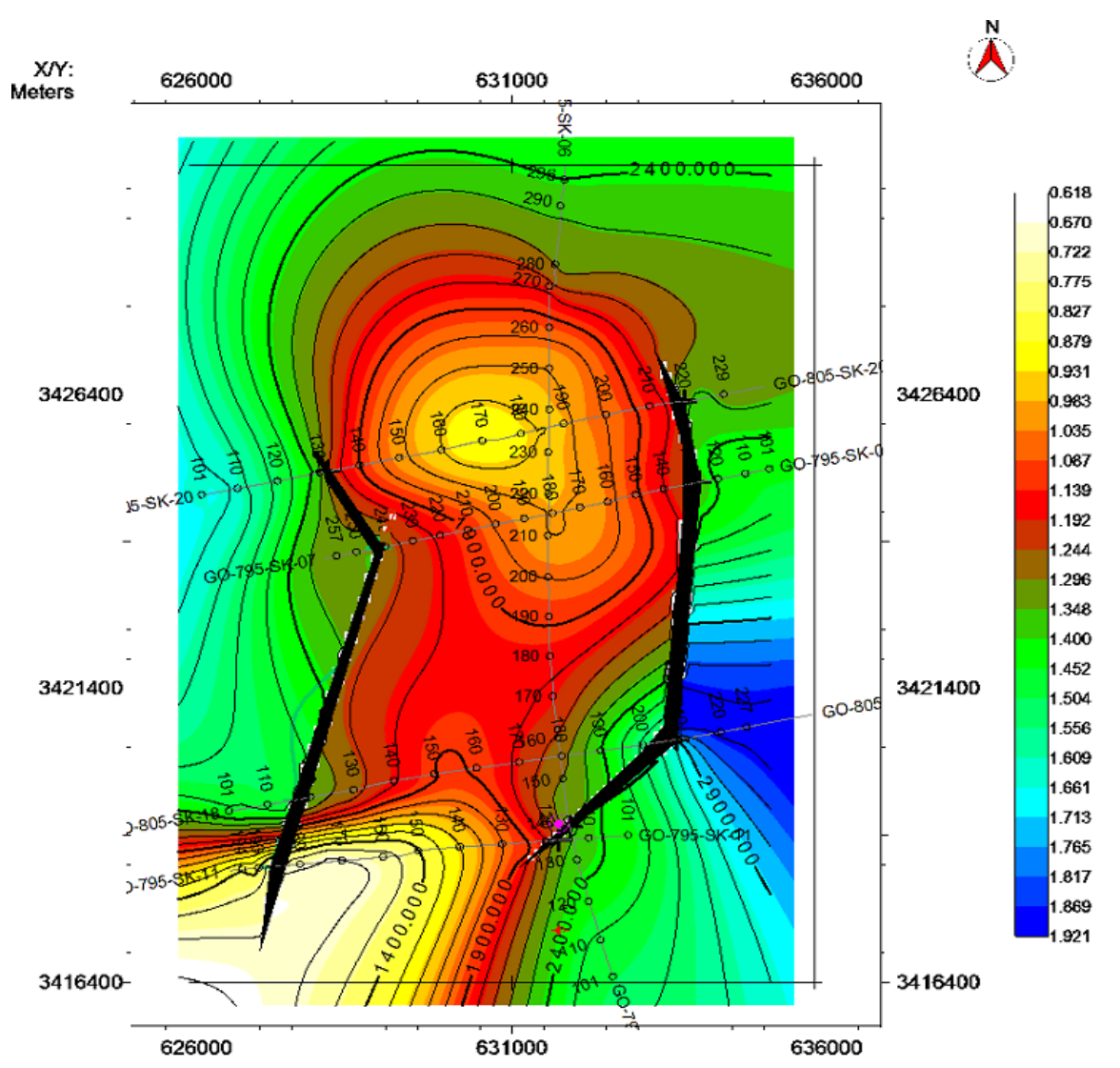

Figure 12. Depth contour map of Rubbly Limestone 


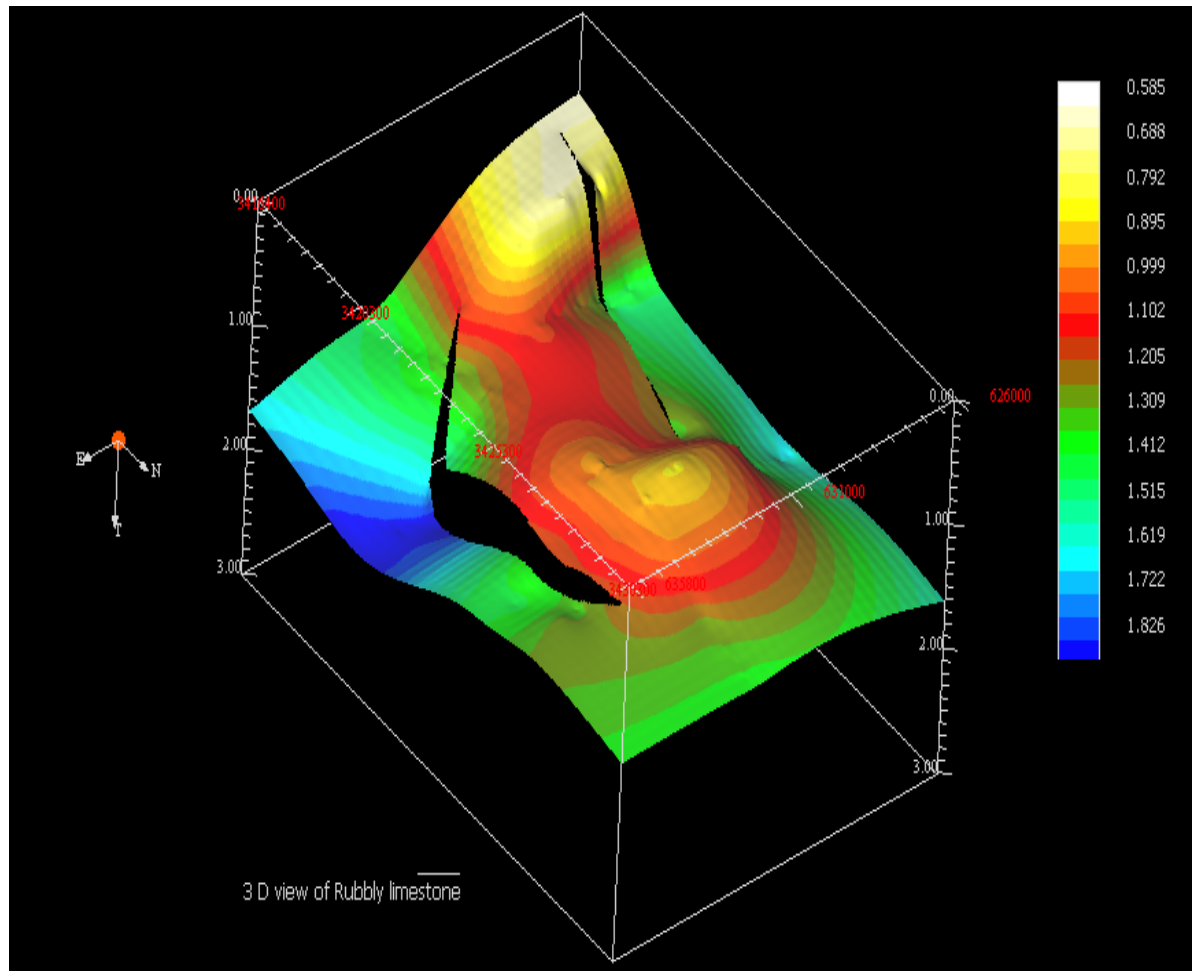

Figure 13. 3 D Surface Time contour of Rubbly Limestone

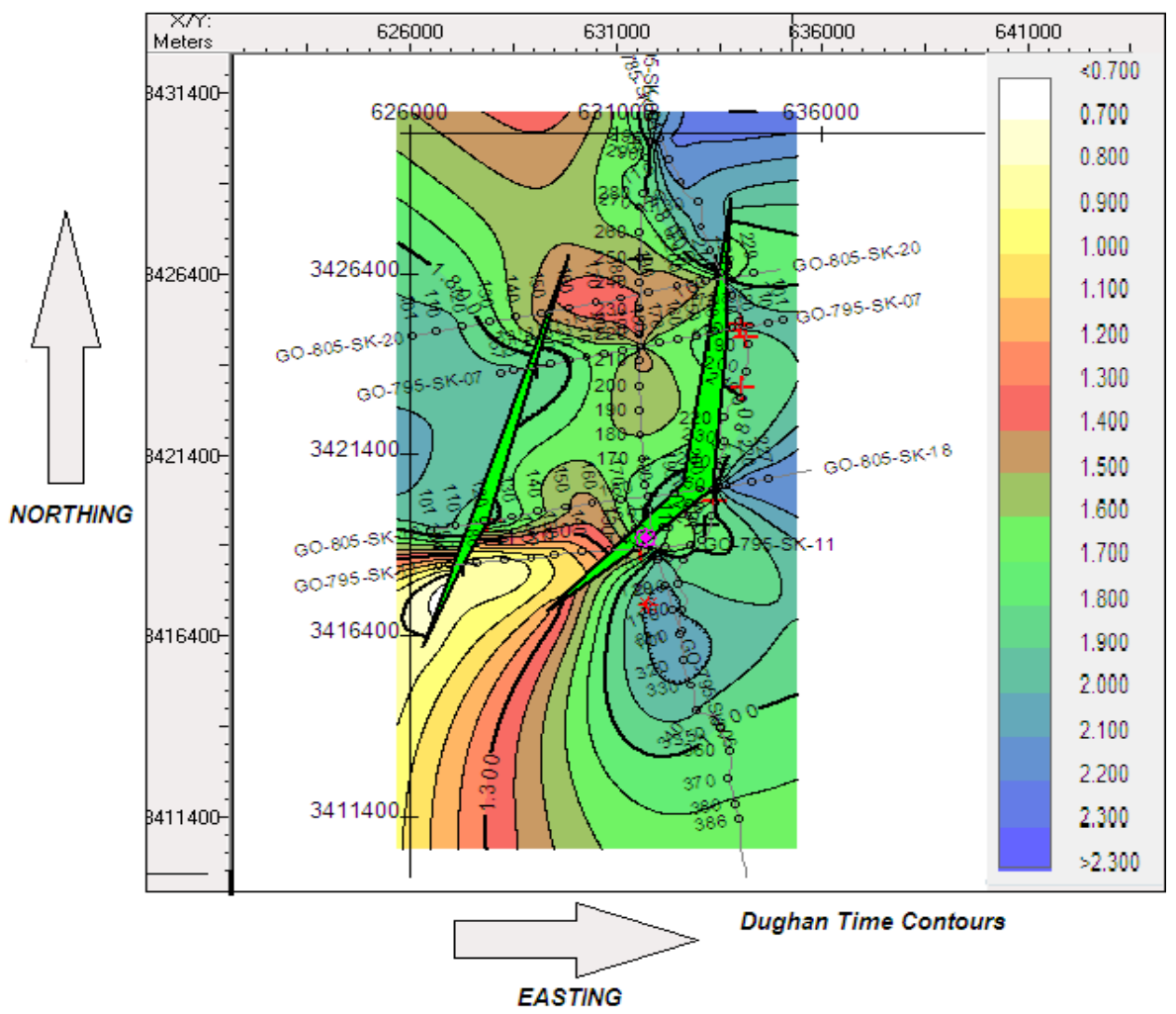

Figure 14. Time contour map of Dunghan Limestone 


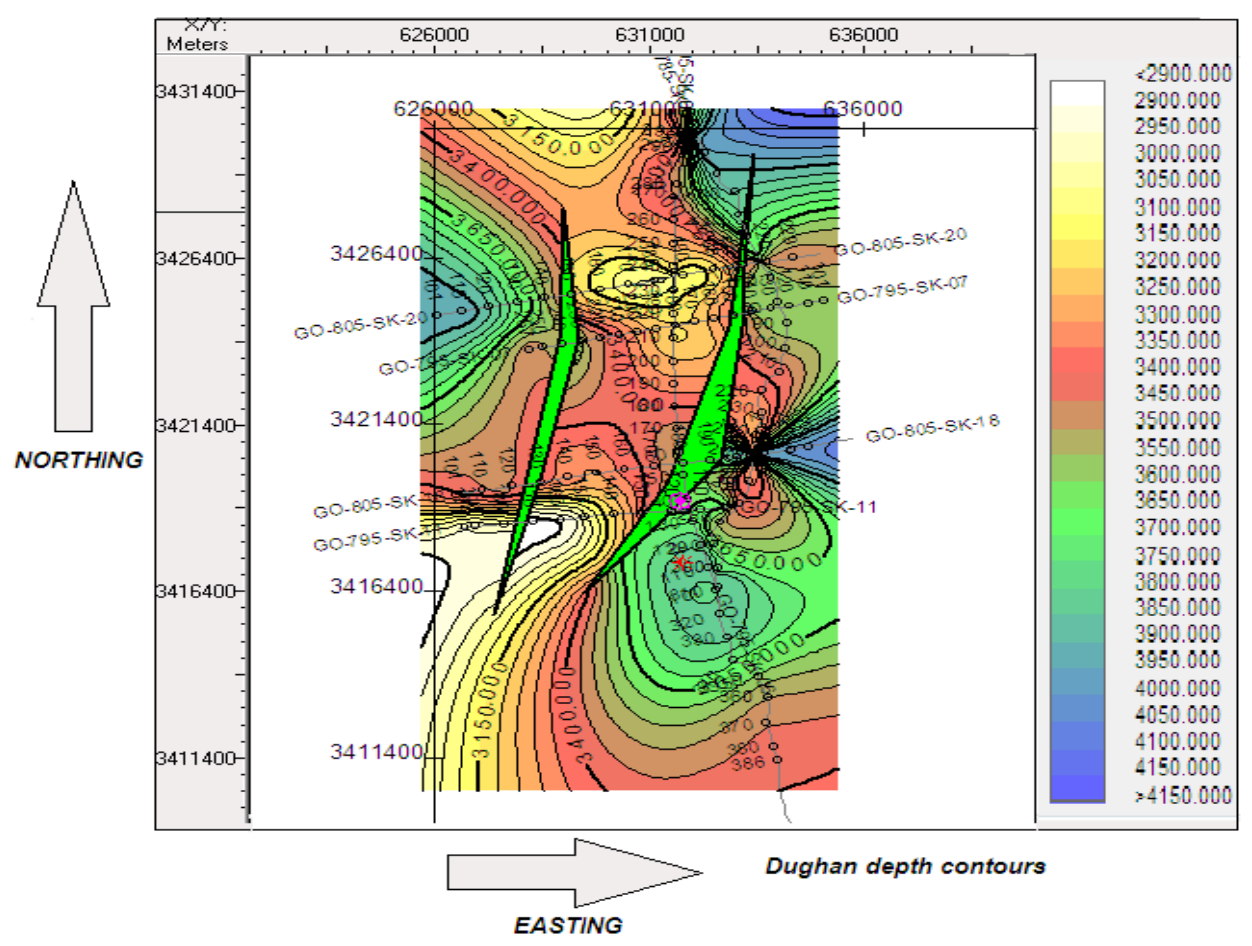

Figure 15. Depth contour map of Dunghan Limestone

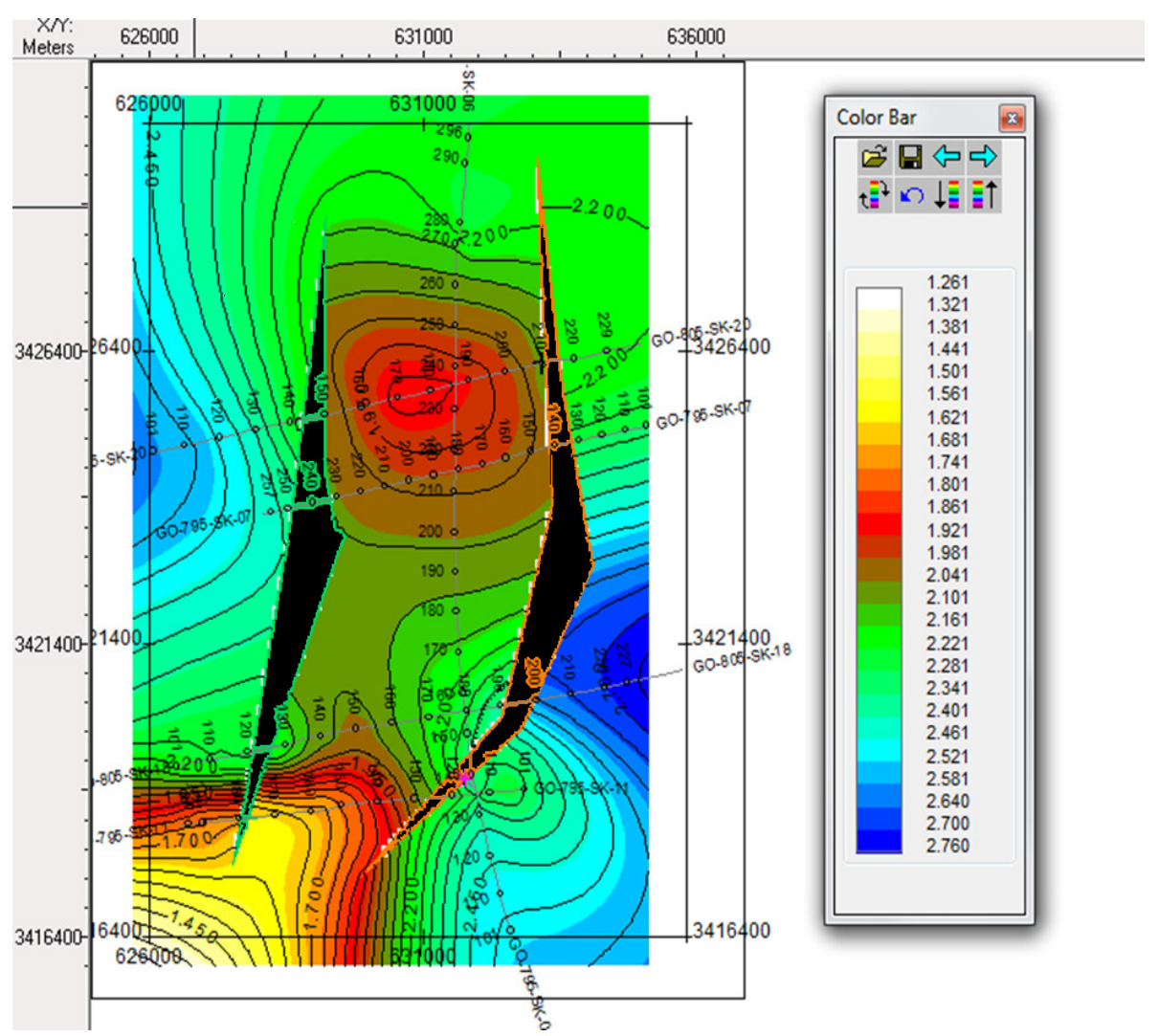

Figure 16. Time contour map of Lower Goru Formation in seconds. 


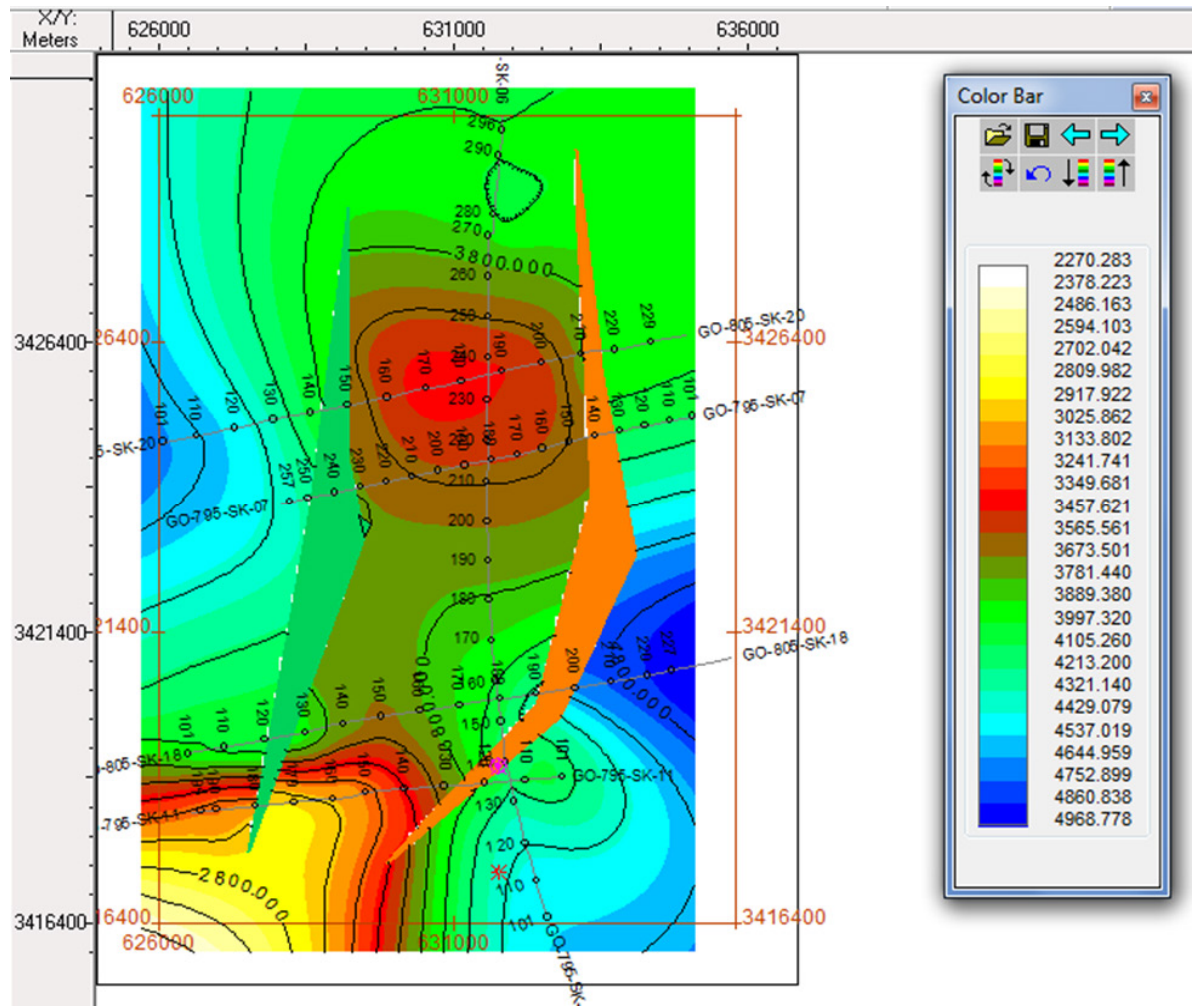

Figure 17. Depth contour map of Lower Goru Formation in meters

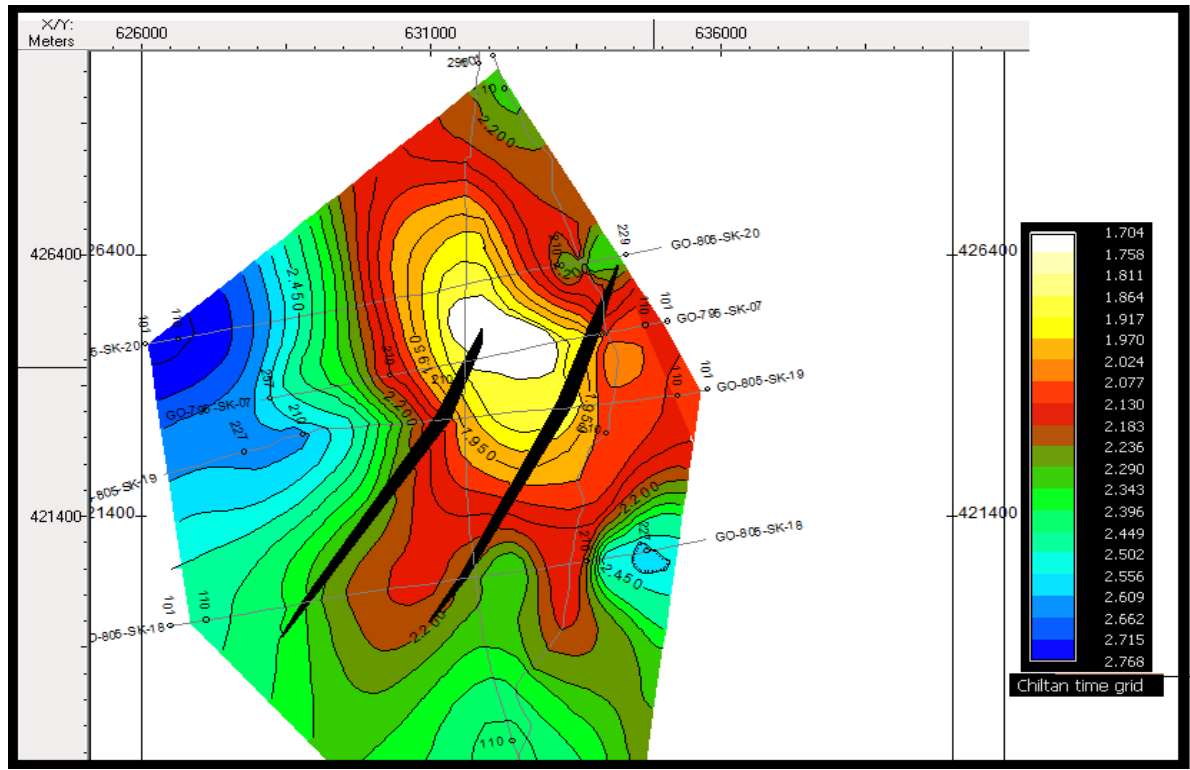

Figure 18. Time contour map of Chilton Formation 


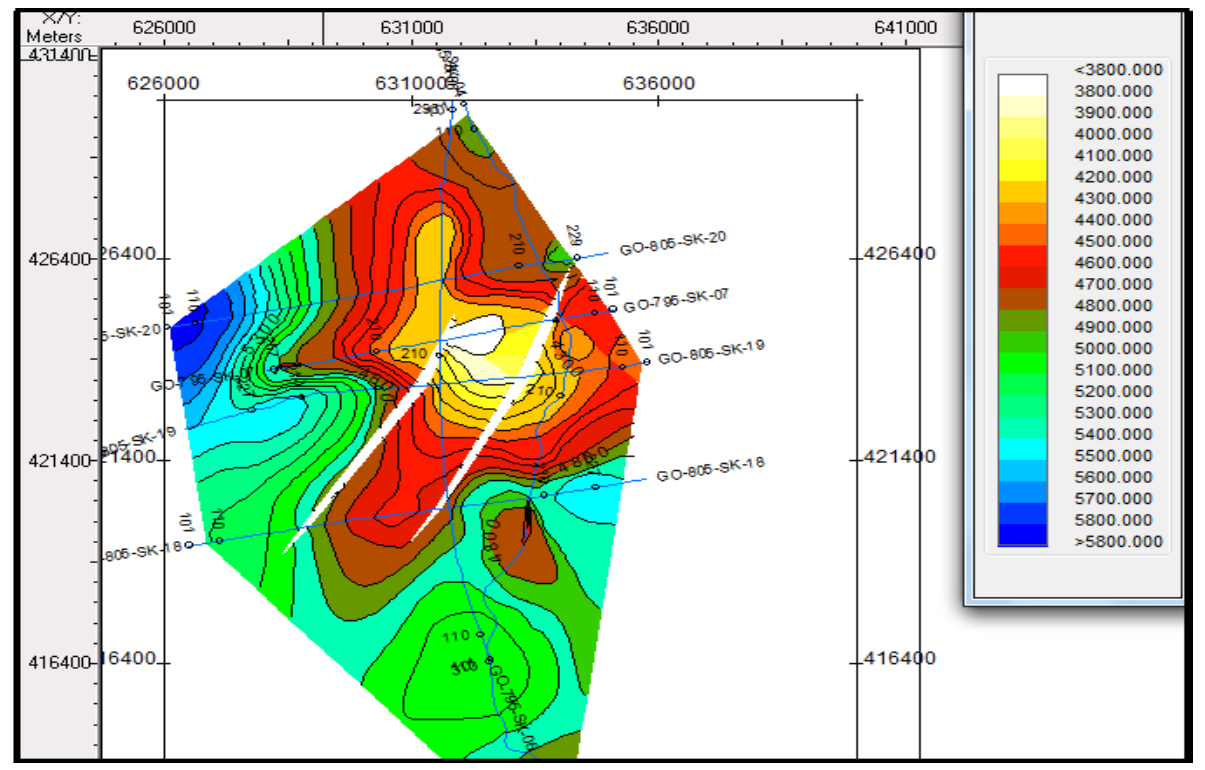

Figure 19. Depth contour map of Chilton Formation

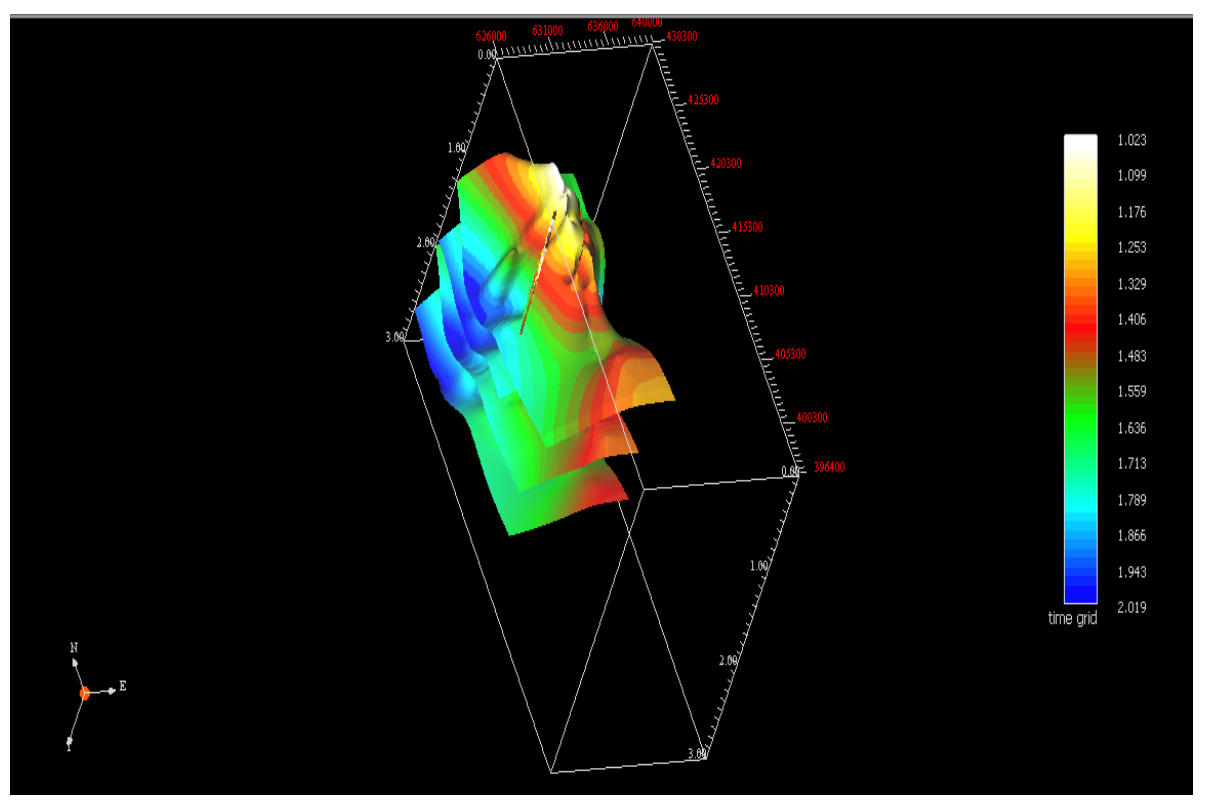

Figure 20. 3D surface view of all formations

\section{Rock Physics Modeling of Chilton Formation}

\subsection{Compressional Wave Velocity}

$\mathrm{P}$ wave velocity shows that there is lithological variation present in the Chiltan Formation. A zone where the velocity is decreasing may be identified as a potential zone for Hydrocarbon search. The 3D horizontal slice of Chiltan formation at $2.5 \mathrm{sec}$ indicates the anomalous zone where $\mathrm{P}$ wave velocity has low values while the region around this zone has relatively high values of velocity. Hydrocarbon reservoirs are characterized by low velocities (fig 21). 


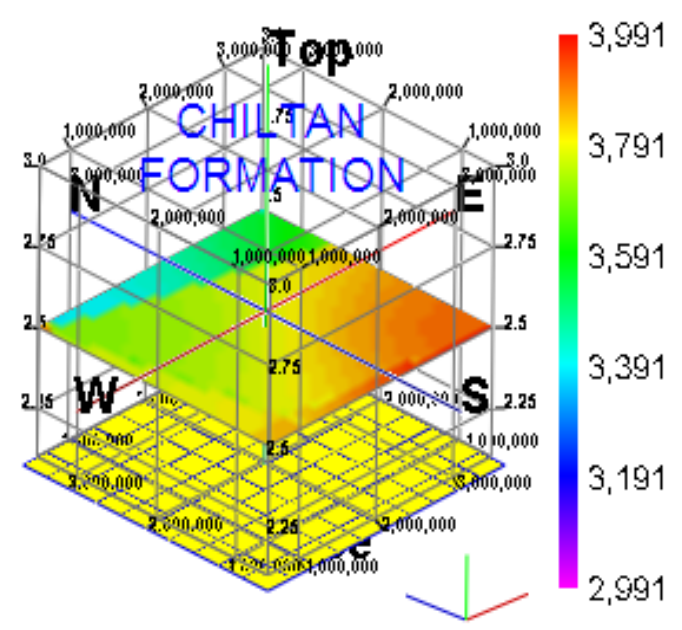

Figure 21. 3D Horizontal slice of Chiltan Formation at $2.5 \mathrm{sec}$

In the 2-D modeling only the vertical view is generated to show that how the $P$ wave velocity varies through the vertical extension of formation. In this $2 \mathrm{D}$ view the thickness of the zone having low value of velocity shown in Fig 22

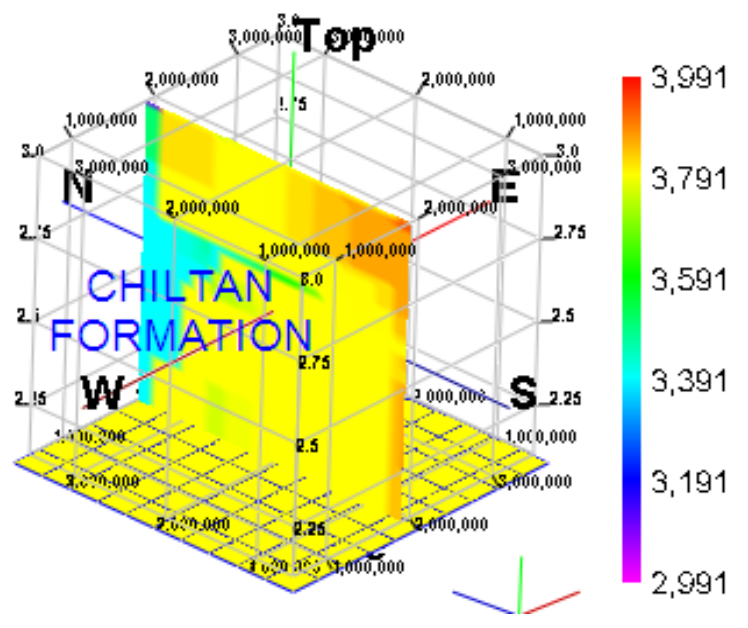

Figure 22. 2D N-S slice of Chiltan Formation.

\subsection{Vp/Vs Ratio}

In the 3D model, slice of Chiltan Formation at $2.5 \mathrm{sec}$ indicates a zone in which the values of the velocity ratio are comparatively higher than the surroundings. This is the zone which has some reservoir potential. The low value of the velocity ratio in the adjoining areas of the anomalous zone indicates that most of the portion of Chiltan Formation is compact (fig 23).

Same results are shown in this $2 \mathrm{D}$ model as indicated in the 3D model. Model has complete lithological information of the Chiltan Formation because of the presentation of Chiltan Formation in N-S. Through the study of 2D model of velocity ratio it can be conclude that most part of the formation consists of compacted carbonates with very low porosity because the value of $\mathrm{Vp} / \mathrm{Vs}$ ratio is high in the small patch of the slice indicator of the porous zone as shown in figure 24 .

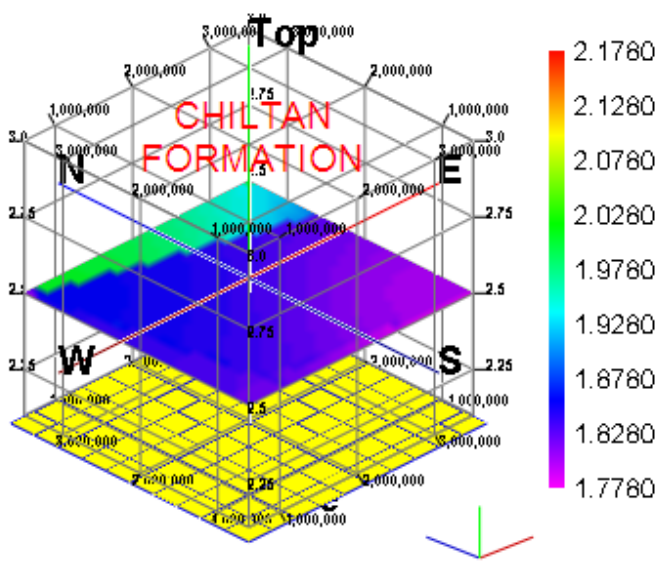

Figure 23. 3D slice of Velocity ratio of Chiltan Formation at $2.5 \mathrm{sec}$

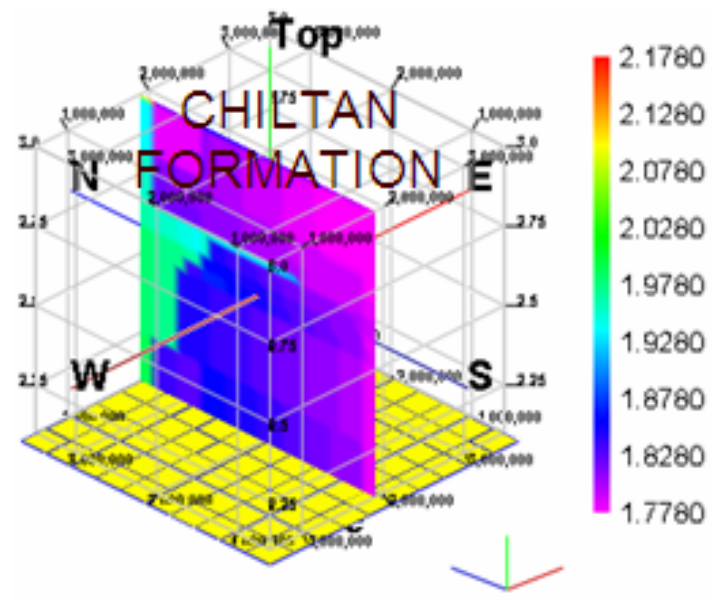

Figure 24. 2D view of velocity ratio in N-S direction

\subsection{Bulk Modulus of Chiltan Formation}

3D model of bulks modulus is generated. Bulks modulus is also an important factor for the lithology separation. In this model there is an anomalous zone is indicated where the bulks modulus have low value because this physical property decreases in the strata having pours in it may be the potential zone for hydrocarbon search (fig 25).

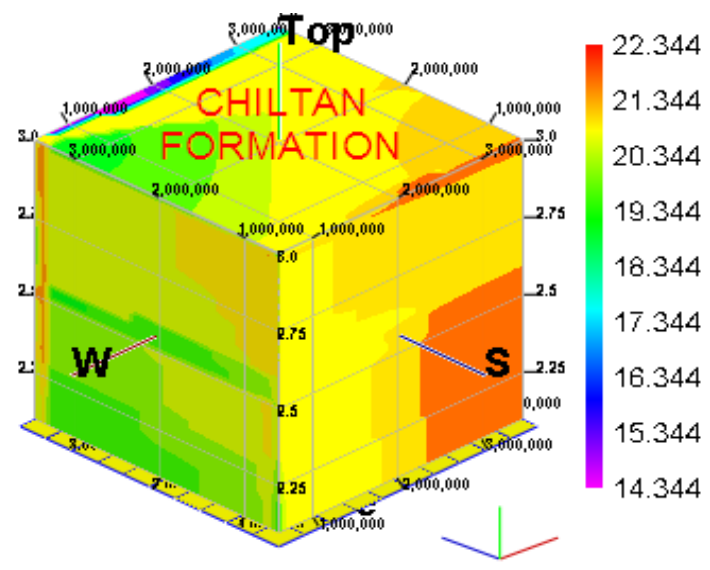

Figure 25. $3 \mathrm{~d}$ model of Bulks modulus of Chiltan Formation 


\subsection{Shear Modulus}

3D model of Chiltan Formation of Shear modulus also have the same anomalous zone as the reservoir region is characterized by the low values of shear modulus (fig 26).

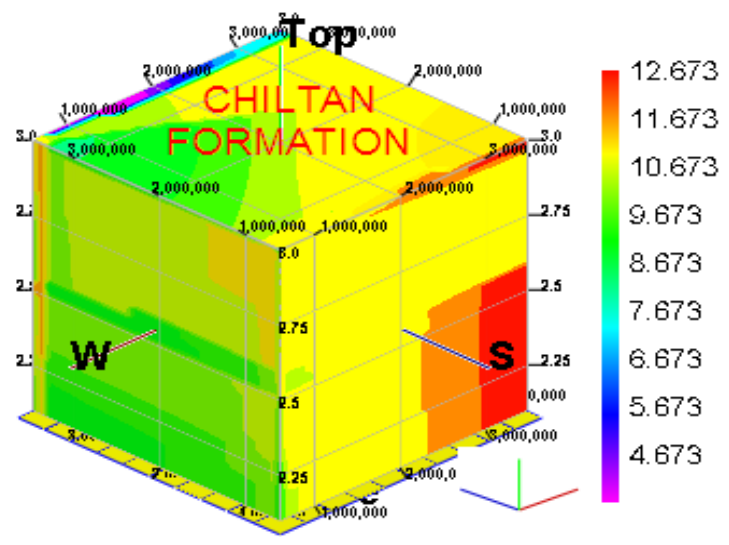

Figure 26. over all model of Chiltan Formation

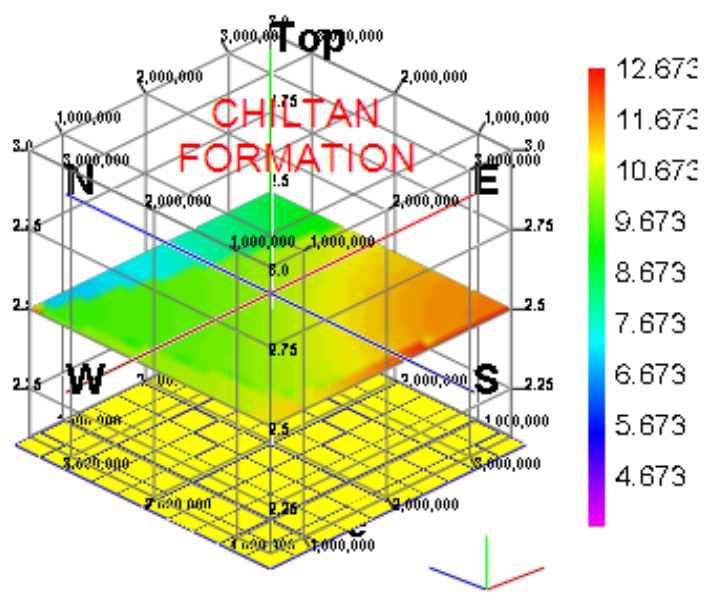

Figure 27. Slice of denisty at $2.5 \mathrm{sec}$

2D model of shear modulus of Chiltan formation and the slice is taken at $2.5 \mathrm{msec}$. Model representing zone of interest indicated by the shear modulus have low value (fig 27).

\section{Depth Model of Four Culminations of Safed Koh Trend}

Safed-koh Trend is located in D.G.Khan district, Punjab province. It is $100 \mathrm{Km}$ north-south trending anticlines in a Fault Propagation Folded Zone, in the east of Sulaiman fold belt. Safed-koh is exposed as a first line of Folding on the Folded Flank of Sulaiman Foredeep. To the north it is separated by Pezu Transverse uplift whereas in the South by Mari Bugti. In the East the Punjab Monocline is a stable area and the Sulaiman Fold and Thrust belt makes the western boundary of the area. Dhodak, Rodho, Afiband and Zindapir anticlines are the four culminations of Safed-Koh Trend. Basemap in figure 28 shows the seismic lines used for the preparation of depth cross-section (fig 29). The results combined with a surface geology are as follows:

Dhodak is the northern lower most culmination. The sediments of Kirthar Formation, Nari-Gaj Formation and Siwaliks are exposed. It is an asymmetrical anticlinal fold. The axis is north-south trending. A cross-section shows amplitude of Dhodak structure is above $500 \mathrm{~m}$. Thrust fault cuts the flank of Dhodak structure dips in south. It is separated from a Rodho anticline in south by a narrow syncline. A Thrust fault cuts the southern side of Dhodak structure dips in north. By comparing the data of Dhodak-01 and Rodho-01 wells, the increase in thickness in Ghazij Formation is observed northwards.

Rodho is the second culmination from north and lower than Afiband anticline. The northern flank of this syncline is steeper and the southern flank is broader. When the data of Dhodak-01 and Rodho- 01 well tops is compared the increase in thickness in Upper Ranikot Formation and Lower Ranikot Formation is observed southwards. Dunghan is thinning in Rodho-01.

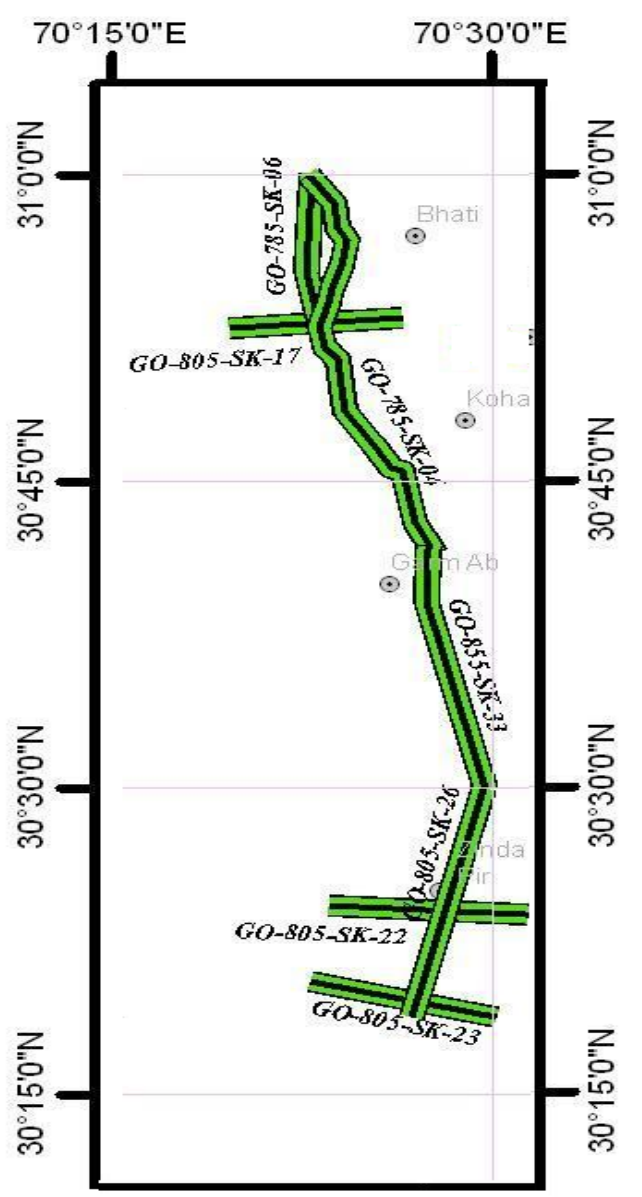

Figure 28. Basemap showing the location of Seismic lines used in construction of Safed Koh Trend Depth cross section 


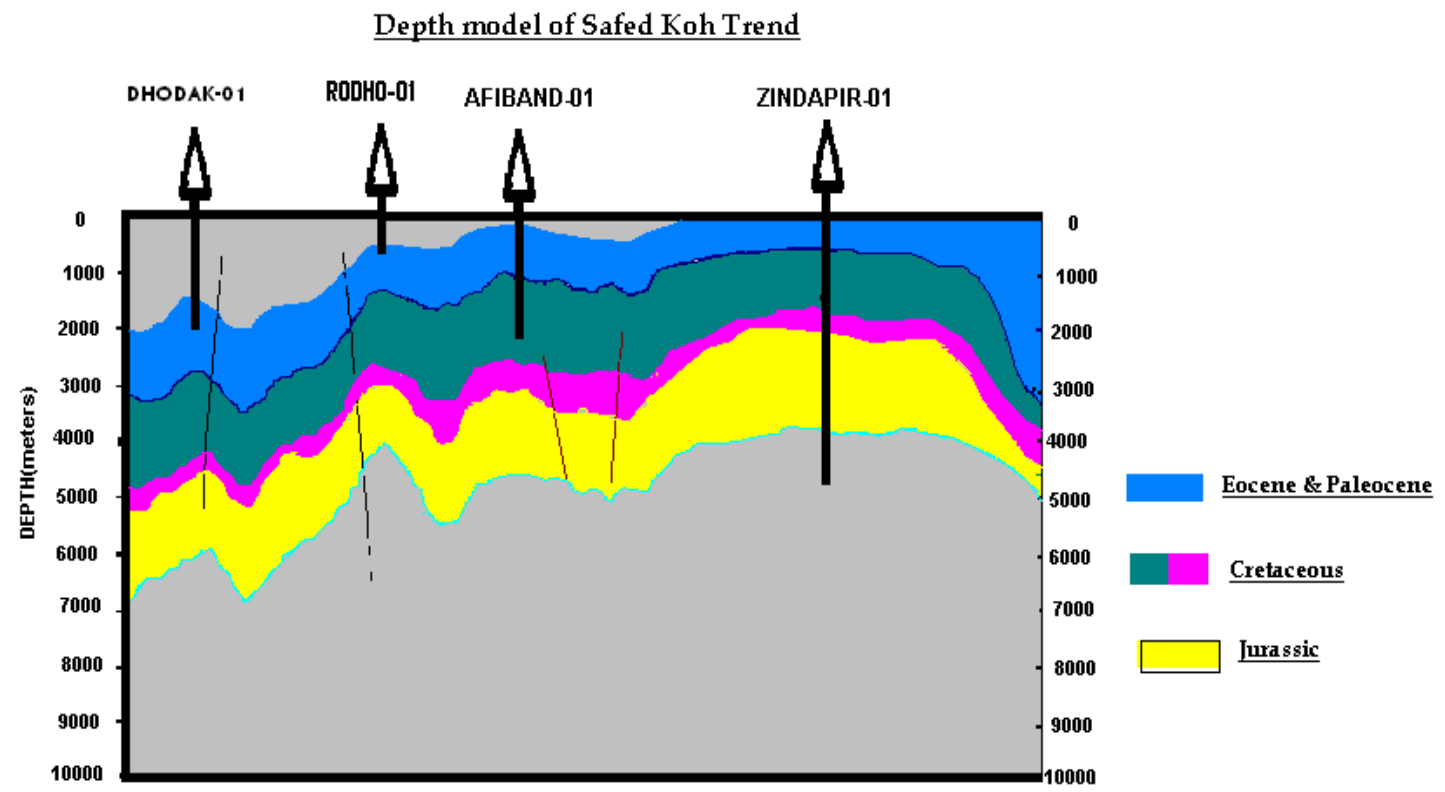

Figure 29. Depth model of Safed Koh Trend (Dhodak structure lies in north)

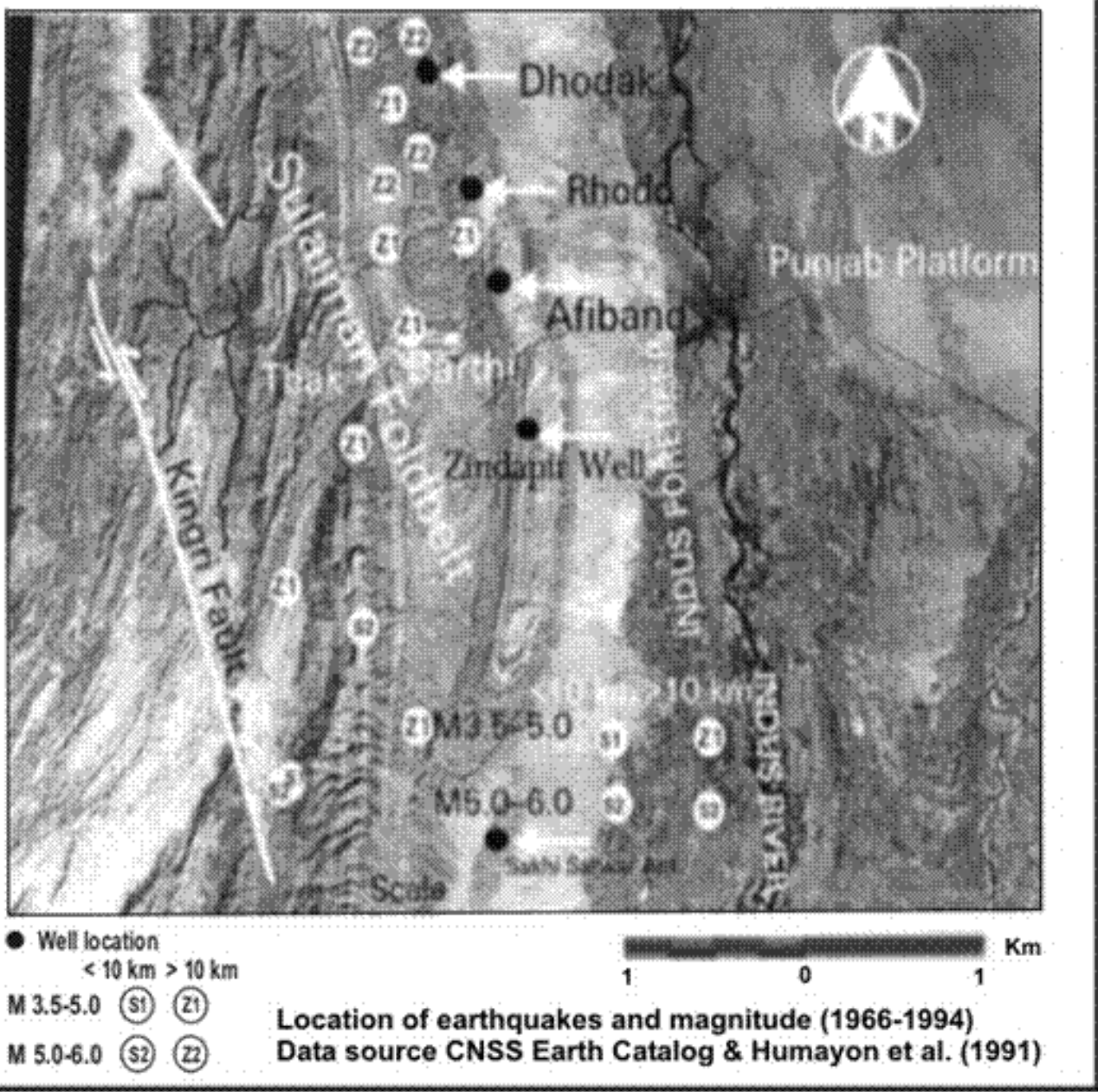

Figure 30. Map showing the Safed Koh Trend and various seismic events. (http://disc.sci.gsfc.nasa.gov) 
Afiband is a third culmination of the Safed-Koh Trend. Subsurface picture shows a low amplitude broad folded anticline as compare to Rodho and Dhodak. Crest shifts towards north in the subsurface cross-section. Syncline is separating Afiband anticline with Zinda Pir Anticline.

Zindapir is the southern culmination of Safed-Koh Trend. It is most uplifted and broader structure comparatively.

\section{Petroleum Aspect}

Dunghan Formation and Ranikot Formation in this area have already proved to be good quality reservoirs. Pab Formation of Cretaceous and Chilton Formation of Jurassic could also be the important reservoirs in Dhodak anticline. The anticlines are converging with depth and also the syncline separating them becomes steeper with depth, and the faults near the crests of Dhodak and Rodho might have provided the migration path for oil/gas, which has accumulated along their crests and thick Ghazij shales have built up the high pressure above them. Chilton Formation is not encountered in Dhodak well. The synclinal structure or may be a down thrown block bounded by faults, buried the source at greater depth for generation of hydrocarbon. The southward advancing nappes were met with increasing friction along the Sulaiman Basement Fault. This caused the synclines to be squeezed out between the anticlines in the Sulaiman Anticlinorium and resulted in uplift of the Sulaiman Range (Raza, 1990). The erosion of Himalayas provided the rapid thick deposition of Eocene sediments which resulted in an increase in the over burden pressure and subsidence of the source rock. Potential source rocks are the Jurassic shales, Sember shale and Mughalkot Formation of the Cretaceous. There are close relations between compressive features and strike-slip faults in this area. Whereas, based on occurrence of earthquakes between 1966-1994 reveals concentration of high magnitude earthquakes at a depth of more than 30 kilometers. It suggests that the basement of the Indo-Pakistan is involved in structural deformation of Zindapir Anticlinorium (Fig 30 \& 31) and its surroundings (Iqbal et al., 2004).

Earthquake studies (Quittmeyer et al., 1984) demonstrate that two earthquakes originated in the superficial structure, whereas two other recorded earthquakes resulted from thrusting in the basement. Such a differentiation between earthquakes is only possible when the upper layer of the crust has detached itself from the basement. The regional structure also indicates that the Kingri fault and associated folds are the result of detachment; the structure is indeed similar to that of other thrust and fold belts characterized by detachment.

Thick Infracambrian evaporites, probably correlative to the Hormuz salts of Iran, provided the detachment surface for apparent décollement movements.

The successive breaching of Tertiary formations of the Zinda Pir anticline reveals in its core the same Paleocene rocks that host the gas in the Sui anticline. These rocks were the prime target in two wells drilled in the northern end of the anticline where the Paleocene formations had plunged beneath a cover of younger Tertiary rocks (disc.sci.gsfc.nasa.gov). A $10 \mathrm{~km}$ thick stratigraphic section outcrops at the deformation front. Available evidence suggests detachment of nearly all the stratigraphic sections from the crystalline basement (Jadoon et al; 1993). Figure 32 shows the two way time of cretaceous sediments is around 1 sec in Safed-|koh Trend and they get deeper around $4 \mathrm{sec}$ in Sulaiman Foredeep.

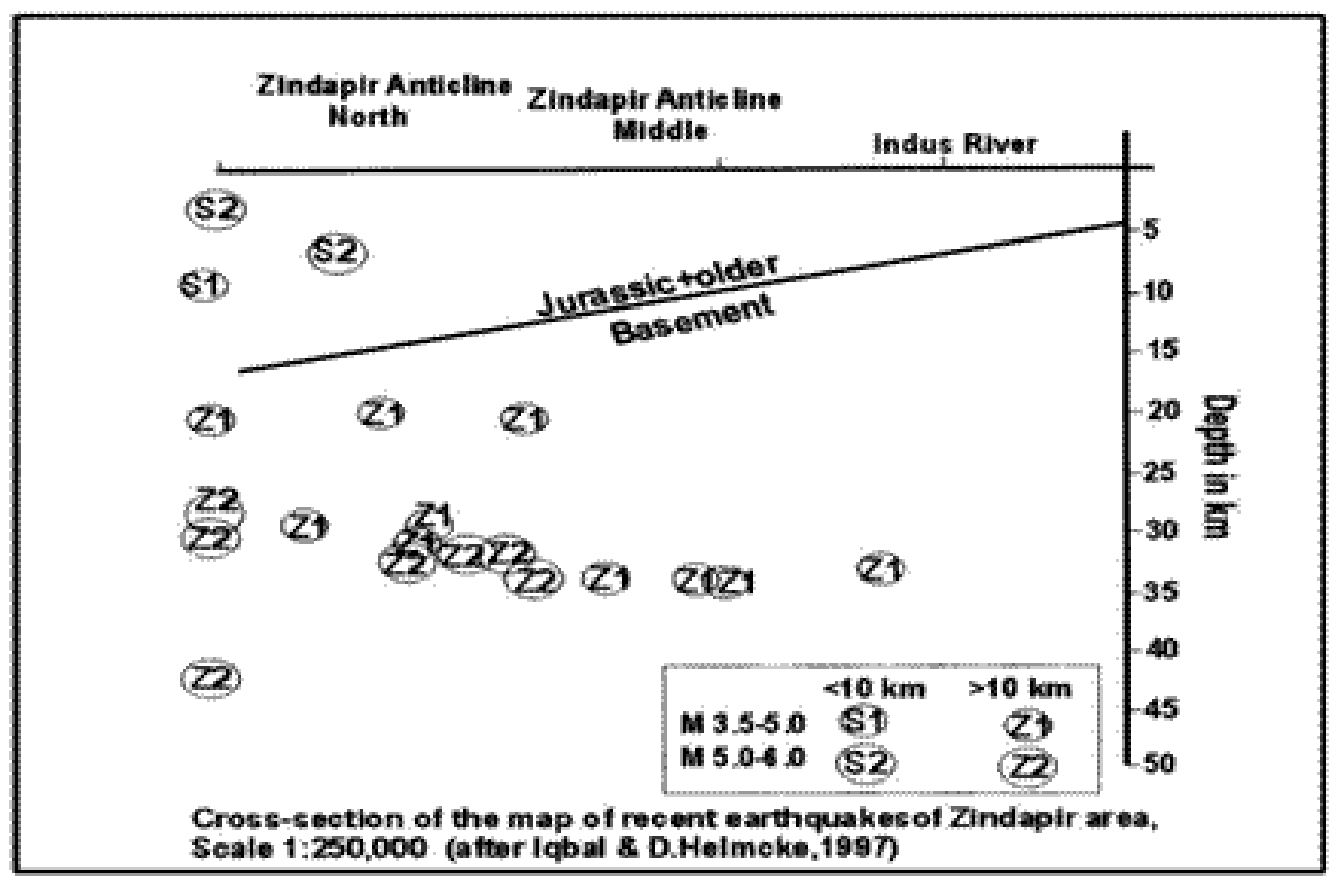

Figure 31. Plot of earthquakes of Zindapir area (Iqbal \& D.Helmoke, 1997). 


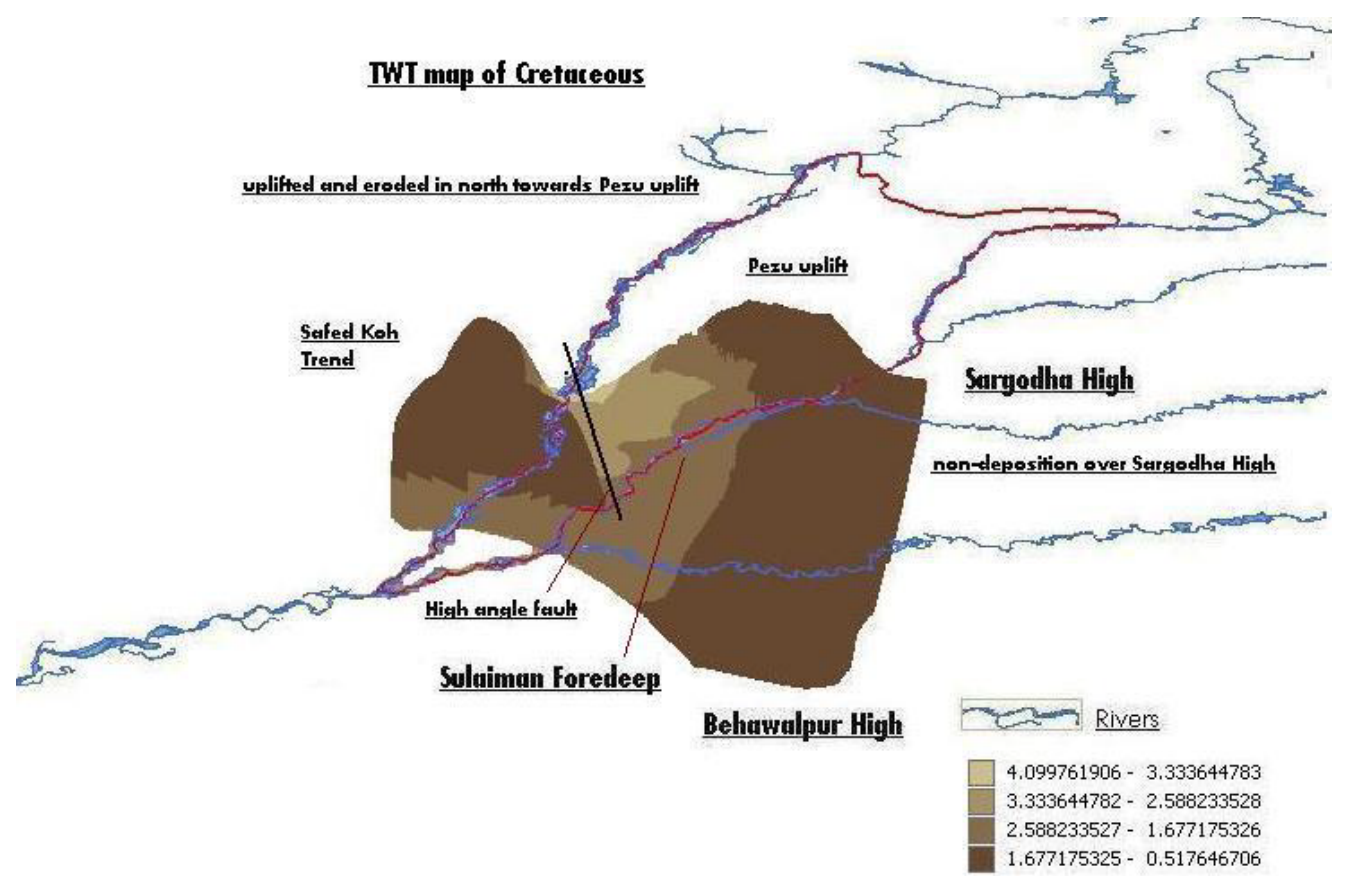

Figure 32. 3D sub-surface view of Cretaceous sediments

\section{Conclusions}

The time \& depth contour maps show the formations of Eocene-Jurassic age in Dhodak pop up structure bounded by reverse faults. The 3D subsurface view of all formations give a better picture. Depth Model of Safed Koh Trend shows the four culminations (Dhodak, Rodho, Afiband and Zindapir) of the detached north south plunging fold of which Zindapir is the most uplifted one. rock physics analysis shows that Chilton Formation has potential for Hydrocarbons.

\section{Recommendations}

Lower Goru Formation and Chiltan \& Alozai Formations of Mesozoic act as a good reservoir rocks whereas the overlying shales provide the good seals. The sources are also buried deep in order to attain the maturity levels. Mesozoic sediments should be explored for hydrocarbons in future.

\section{Acknowledgement}

Directorate General of Petroleum Concessions and LMKR are greatly acknowledged for providing the Research data. IHS is also acknowledged for giving academic license for SMT Kingdom software.

\section{REFERENCES}

[1] Humayun, M., Lillie, R. J. Lawrence, R. D., 1991. Structural interpretation of the eastern Sulaiman fold belt and foredeep, Pakistan. Tectonics, 10: 299-324.
[2] Jadoon, I.A.K., Lawrence, R.D., Lillie, R.J., 1992. "Balanced and Retro deformed geological cross-section from the Frontal Sulaiman Lobe, Pakistan; Duplex development in thick strata along the western margin of the Indian Plate. In.; McClay, K. (ed.) Thrust tectonics. Chapman Hall, London, 343-356.

[3] Jadoon, I.A.K., R. D. Lawrence \& R. J. Lillie, 1993 , Geological Society, London, Special Publications;; v. 74; p. 589-602.

[4] Jadoon, I.A.K., R.D. Lawrence and R.J. Lillie, 1994, Seismic data, geometry, evolution and shortening in the active Sulaiman fold-and-thrust belt of Pakistan; Amer. Assoc. Petroleum Geol. Bull., 78, p.758-774.

[5] Kadri, 1995, Petroleum Geology of Pakistan, p34.

[6] Kemal, A., Balkwill, H.R. \& Stoakes, F.A., 1991, “ Indus Basin Hydrocarbons plays", International Petroleum Seminar on new directions and stratigies for accelerating Petrolen Exploration and Production in Pakistan.

[7] Lillie, R.J., Johnson, G.D., Yousaf, M. Zamin, A.S.H. \& Yeats, R. S. ; 1987. "Structural development within the Himalayan Foreland Fold-and Thrust Belt of Pakistan. In.: Beaumont \& Tankard (eds.) Sedimentary Basins and Basin-Forming Mechanisms. Can.Soc. Petro. Geol., Memoir. $12: 379-392$

[8] Iqbal, M and Helmcke, D., 2004, Pakistan journal of Hydrocarbon Research, Vol 14, pg 41- 47, Geological interpretation of Earth quakes data of Zinda Pir Anticlinorium, Sulaiman Fold Belt,Pakistan).

[9] Quittmeyer, R. C., Kaffa. A. A. \& Armbruster, J. G., 1984, "Focal mechanism and depths of Earth quakes in Central Pakistan; A tectonic interpretation. J. Geophysics. Res., 89; 2459-2470

[10] Raza, H. A., Ahmed, R., Ali, S. M., \& Ahmad, J. (1989): "Petroleum prospects Sulaiman Sub Basin, Pakistan.Pakistan Journal of Hydrocarbon, Res. 1, 2; 21-56; Islamabad.

[11] Raza, H.A. \& Ahmed, R., 1990, Hydrocarbon Potential of Pakistan. Journal. Canada- Pakistan Cooperation Ottawa. 4 (1): 9-27. 